Article

\title{
Se-Cl Interactions in Selenite Chlorides: A Theoretical Study
}

\author{
Sergey V. Krivovichev ${ }^{1,2, *}$ and Liudmila A. Gorelova 2 (D) \\ 1 Nanomaterials Research Centre, Kola Science Centre, Russian Academy of Sciences, Fersman str. 14, \\ 184209 Apatity, Russia \\ 2 Department of Crystallography, Institute of Earth Sciences, St. Petersburg State University, \\ University Emb. 7/9, 199034 St. Petersburg, Russia; gorelova.ljudmila@gmail.com \\ * Correspondence: s.krivovichev@spbu.ru; Tel.: +7-81555-75-350
}

Received: 29 March 2018; Accepted: 25 April 2018; Published: 29 April 2018

check for updates

\begin{abstract}
The Se-Cl interactions in five selenite chlorides $\left(\alpha, \beta-\mathrm{Zn}_{2}\left(\mathrm{SeO}_{3}\right) \mathrm{Cl}_{2}\right.$ (sofiite and its polymorph), $\alpha, \beta-\mathrm{Cu}_{5} \mathrm{O}_{2}\left(\mathrm{SeO}_{3}\right)_{2} \mathrm{Cl}_{2}$ (georgbokiite and parageorgbokiite), and $\mathrm{KCdCu}_{7} \mathrm{O}_{2}\left(\mathrm{SeO}_{3}\right)_{2} \mathrm{Cl}_{9}$ (burnsite)) have been investigated by means of the analysis of their theoretical electron density distributions. The analysis reveals the existence in the structures of two basic types of interactions: intermediate interactions with essential covalent contribution and closed-shell interactions. In $\mathrm{Zn}_{2}\left(\mathrm{SeO}_{3}\right) \mathrm{Cl}_{2}$ polymorphs and burnsite, all metal-oxide and metal-chloride interactions are of the first type, whereas in georgbokiite and parageorgbokiite, the Jahn-Teller distortion results in the elongation of some of the $\mathrm{Cu}-\mathrm{X}$ bonds and their transition to the closed-shell type. All anion-anion interactions are of the closed-shell type. The energy of the closed-shell $\mathrm{Se}-\mathrm{Cl}$ interactions can be estimated as $1.4-2.6 \mathrm{kcal} \cdot \mathrm{mol}^{-1}$, which is comparable to weak hydrogen bonds. Despite their weakness, these interactions provide additional stabilization of structural architectures. The $\mathrm{Se}^{4+}-\mathrm{Cl}^{-}$ configurations are localized inside framework channels or cavities, which can be therefore be viewed as regions of weak and soft interactions in the structure.
\end{abstract}

Keywords: selenite; chloride; crystal structure; copper; zinc; electron density; closed-shell interactions; halogen bond; sophiite; georgbokiite

\section{Introduction}

According to the last version of the Inorganic Crystal Structure Database (ICSD) [1], there are about 130 structurally characterized inorganic compounds containing $\mathrm{Se}, \mathrm{O}$, and $\mathrm{Cl}$, and more than 95 of them are selenite chlorides, i.e., the compounds containing both $\left(\mathrm{Se}^{4+} \mathrm{O}_{3}\right)^{2-}$ and $\mathrm{Cl}^{-}$ anions. No selenate chlorides have been reported in the literature to the present date. The high affinity of selenite and chloride anions is obvious and requires a chemically reasonable explanation. The problem is also important from the viewpoint of interesting physical properties of transitional metal selenite chlorides [1-11] and their mineralogical occurrences [12-23]. Indeed, many transitional metal selenite chlorides display diverse magnetic properties, due to the presence in their structures of low-dimensional arrays of magnetic ions such as $\mathrm{Cu}^{2+}, \mathrm{Ni}^{2+}, \mathrm{Co}^{2+}$, and $\mathrm{Fe}^{2+}$ [11]. The eruption of Tolbachik volcano (Kamchatka peninsula, Russia) in 1975-1976 was followed by the extensive fumarolic activity, which was accompanied, in particular, by the formation of selenite chloride mineral associations dominated by $\mathrm{Cu}^{2+}$-containing species $[12,14-16,18-20,22,23]$.

Johnsson et al. [24] noted that the tendency of lone-electron pair cations such as $\mathrm{Se}^{4+}$ and $\mathrm{Te}^{4+}$ to associate with halide ions results in the agglomeration of halides and lone pairs into separate regions in the crystal structure, which act as 'chemical scissors', subdiving the structure space into relatively hard and covalently bonded metal-oxide parts and relatively soft halide-lone-pair parts. However, 
the chemical nature of the halide-lone-pair association remained unclear. The aim of the present paper is to investigate interactions between $\mathrm{Se}^{4+}$ and $\mathrm{Cl}^{-}$ions in selenite chlorides from a theoretical point of view, using the 'Atoms-in-Molecules' (AIM) theory [25] in order to shed some light on the existence of these compounds and their abundance compared to selenate chlorides.

\section{Materials and Methods}

According to this approach, the presence of a $(3,-1)$ bond critical point (bcp) along the interatomic line (bond path) in the electron-density distribution, $\rho(\mathbf{r})$, unambiguously manifests the existence of a bonding interaction between the respective pair of atoms. The properties of the bcps provide a unique set of descriptors that can be used to understand the nature of interatomic interactions [26]. In particular, the following parameters are of importance: (1) electron density at the bcp, $\rho\left(\mathbf{r}_{\mathbf{c}}\right)$ (here and in the following $\mathbf{r}_{\mathbf{c}}$ is a radius vector of the bcp); (2) Laplacian of the electron density, $\nabla^{2} \rho\left(\mathbf{r}_{\mathbf{c}}\right)$; (3) electron energy density, $H\left(\mathbf{r}_{\mathbf{c}}\right)$, which is defined as a sum $\left[G\left(\mathbf{r}_{\mathbf{c}}\right)+V\left(\mathbf{r}_{\mathbf{c}}\right)\right]$ of kinetic $\left(G\left(\mathbf{r}_{\mathbf{c}}\right)\right)$ and potential $\left(V\left(\mathbf{r}_{\mathbf{c}}\right)\right)$ energy densities. All chemical interactions can be classified into different groups according to the values of these or derivative parameters. Herein we adopt the classification proposed by Espinosa et al. [27], which is based on the signs of the $\nabla^{2} \rho\left(\mathbf{r}_{\mathfrak{c}}\right)$ and $H\left(\mathbf{r}_{\mathfrak{c}}\right)$ parameters. According to this approach, chemical interactions can be classified as: (1) shared interactions with $\nabla^{2} \rho\left(\mathbf{r}_{\mathbf{c}}\right)<0$ and $H\left(\mathbf{r}_{\mathbf{c}}\right)<0$; (2) closed-shell interactions with $\nabla^{2} \rho\left(\mathbf{r}_{\mathbf{c}}\right)>0$ and $H\left(\mathbf{r}_{\mathbf{c}}\right)>0$; (3) intermediate or transit interactions with $\nabla^{2} \rho\left(\mathbf{r}_{\mathbf{c}}\right)>0$ and $H\left(\mathbf{r}_{\mathbf{c}}\right)<0$. It should be noted, however, that this classification was originally suggested for $\mathrm{F} \cdots \mathrm{H}$ interactions, and its transfer to other interactions is rather conditional.

The laplacian is related to the electron energy densities through the following equation:

$$
\nabla^{2} \rho\left(\mathbf{r}_{\mathbf{c}}\right)=4\left[2 G\left(\mathbf{r}_{\mathbf{c}}\right)+V\left(\mathbf{r}_{\mathbf{c}}\right)\right]
$$

which means that $\nabla^{2} \rho\left(\mathbf{r}_{\mathbf{c}}\right)<0$ only if $\left|V\left(\mathbf{r}_{\mathbf{c}}\right)\right| / G\left(\mathbf{r}_{\mathbf{c}}\right)>2$, since $G\left(\mathbf{r}_{\mathbf{c}}\right)$ is always positive, whereas $V\left(\mathbf{r}_{\mathbf{c}}\right)$ is always negative. Consequently, $\left|V\left(\mathbf{r}_{\mathfrak{c}}\right)\right| / G\left(\mathbf{r}_{\mathbf{c}}\right)>2$ for shared interactions, $2>\left|V\left(\mathbf{r}_{\mathbf{c}}\right)\right| / G\left(\mathbf{r}_{\mathbf{c}}\right)>1$ for intermediate interactions, and $\left|V\left(\mathbf{r}_{\mathbf{c}}\right)\right| / G\left(\mathbf{r}_{\mathbf{c}}\right)<1$ for closed-shell interactions.

Espinosa et al. [27] and Gatti [26] proposed to use the $H\left(\mathbf{r}_{\mathbf{c}}\right) / \rho\left(\mathbf{r}_{\mathbf{c}}\right)$ parameter or bond degree (BD) to measure the degree of covalency of a particular interaction. The lower the BD value, the higher is the covalency of an interaction. The BD value is negative for shared and intermediate interactions and positive for closed-shell interactions.

It has long been recognized that in some ionic crystals (such as LiI [28]), there exist specific anion-anion interactions that stabilize the structure. On the other hand, quantum-chemical calculations of some salts (such as $\mathrm{AlX}_{3}(\mathrm{X}=\mathrm{F}, \mathrm{Cl}, \mathrm{OH})$ [29]) revealed the presence of bcps along the $\mathrm{Al} \cdots \mathrm{Al}$ lines, implying the existence of weak cation-cation $\mathrm{Al} \cdots \mathrm{Al}$ interactions. At first glance, the stabilizing role of such interactions contradicts a traditional crystal-chemical intuition [30], however, the presence of bcps unequivocally indicates that there is a bond path between the corresponding pairs of atoms [31]. Nelyubina et al. [32] and Gibbs et al. [33] provided useful reviews on the subject of anion-anion interactions in various chemical compounds. In particular, Gibbs et al. [33] analyzed the $\mathrm{O}-\mathrm{O}$ interactions along the shared edges of cation coordination polyhedra in silicates and demonstrated that these weak bonds indeed stabilize the structure, though the stabilizing effect might be considered as marginal relative to the metal-oxygen interactions.

In a series of papers, Gibbs et al. [34-36] investigated secondary van der Waals bonding in inorganic molecular crystals such as $\mathrm{As}_{4} \mathrm{~S}_{n}(\mathrm{n}=3,4,5)$ [36], arsenolite, $\mathrm{As}_{2} \mathrm{O}_{3}$ [34], and orpiment, $\mathrm{As}_{2} \mathrm{~S}_{3}$ [35], and reported on the existence of intermolecular closed-shell As-X interactions $(X=O, S)$. The As- $\mathrm{X}$ bonds are directed and are of the Lewis acid-base type, i.e., they link locally concentrated (nucleophilic, Lewis-base) electron density regions on the As atoms to locally depleted (electrophilic, Lewis-acid) electron density regions on the $\mathrm{X}$ atoms. In addition, in some structures, there are also As $\cdots$ As and $\mathrm{O} \cdots$ O interactions. 
For a long time, we have been interested in the crystal chemistry of inorganic oxysalts containing lone-electron-pair cations such as $\mathrm{Pb}^{2+}$ [37-40], $\mathrm{Tl}^{+}$[41], and $\mathrm{Se}^{4+}[42,43]$. In this report, we investigate a number of zinc and copper selenite chlorides from the viewpoint of the analysis of their electron density distributions that may provide novel ideas to understand the role that weak $\mathrm{Se}-\mathrm{Cl}$ closed-shell interactions play in the structural organization of these compounds.

Table 1 provides crystallographic information on the compounds that will be considered in the following. Among the seven compounds, three are naturally occurring selenite chlorides first discovered in the fumaroles of the Tolbachik volcano, Kamchatka, Russia. For the purpose of structure comparison, three pairs of polymorphic modifications have been selected, namely, two modifications of $\mathrm{Zn}_{2}\left(\mathrm{SeO}_{3}\right) \mathrm{Cl}_{2}$, two modifications of $\mathrm{Cu}_{3}\left(\mathrm{SeO}_{3}\right)_{2} \mathrm{Cl}_{2}$, and two modifications of $\mathrm{Cu}_{5} \mathrm{O}_{2}\left(\mathrm{SeO}_{3}\right)_{2} \mathrm{Cl}_{2}$.

Table 1. Crystallographic data for selected selenite chlorides analyzed using the atoms-in-molecules (AIM) theory.

\begin{tabular}{|c|c|c|c|c|c|c|c|}
\hline$\#$ & Chemical Formula & Mineral Name & $\begin{array}{l}\text { Space } \\
\text { Group }\end{array}$ & $\begin{array}{l}a, \AA / \alpha, \\
\text { Deg. }\end{array}$ & $\begin{array}{l}b, \AA / \beta \\
\text { Deg. }\end{array}$ & $\begin{array}{c}c, \AA / \gamma, \\
\text { Deg. }\end{array}$ & Ref. \\
\hline 1 & $\alpha-\mathrm{Zn}_{2}\left(\mathrm{SeO}_{3}\right) \mathrm{Cl}_{2}$ & sofiite & Pccn & $10.251 / 90$ & $15.223 / 90$ & $7.666 / 90$ & [44] \\
\hline 2 & $\beta-\mathrm{Zn}_{2}\left(\mathrm{SeO}_{3}\right) \mathrm{Cl}_{2}$ & - & $P 2_{1} / c$ & $7.670 / 90$ & $10.261 / 100.0$ & $7.657 / 90$ & [45] \\
\hline 3 & $\alpha-\mathrm{Cu}_{5} \mathrm{O}_{2}\left(\mathrm{SeO}_{3}\right)_{2} \mathrm{Cl}_{2}$ & georgbokiite & $P 2_{1} / c$ & $6.030 / 90$ & $13.744 / 95.8$ & $5.562 / 90$ & [46] \\
\hline 4 & $\beta-\mathrm{Cu}_{5} \mathrm{O}_{2}\left(\mathrm{SeO}_{3}\right)_{2} \mathrm{Cl}_{2}$ & parageorgbokiite & $P 2_{1} / c$ & $5.398 / 90$ & $8.054 / 99.3$ & $11.128 / 90$ & [47] \\
\hline 5 & $\mathrm{KCdCu}_{7} \mathrm{O}_{2}\left(\mathrm{SeO}_{3}\right)_{2} \mathrm{Cl}_{9}$ & burnsite & $\mathrm{Pb}_{3} / \mathrm{mmc}$ & $8.781 / 90$ & $8.781 / 90$ & $15.521 / 120$ & [48] \\
\hline
\end{tabular}

The CRYSTAL14 software package was used to perform the solid-state DFT calculations [49]. The Peintinger-Oliveira-Bredow split-valence triple- $\zeta$ (pob-TZVP) basis sets [50] were used for all atoms, except Cd in burnsite [51], along with the hybrid Becke-3-Lee-Yang-Parr (B3LYP) functional. The electron-density distribution function was calculated using experimentally observed geometries for each structure and analyzed using the TOPOND14 software $[52,53]$ with respect to the properties of the bond critical points in electron density distributions and scalar fields of the electron-density Laplacian [53].

\section{Results and Discussion}

\section{1. $\mathrm{Zn}_{2}\left(\mathrm{SeO}_{3}\right) \mathrm{Cl}_{2}$ Polymorphs}

Sophiite, $\alpha-\mathrm{Zn}_{2}\left(\mathrm{SeO}_{3}\right) \mathrm{Cl}_{2}$, was first discovered in fumaroles of the Tolbachik volcano, Kamchatka peninsula, Russia [12]. Its $\beta$-polymorph was synthesized by chemical transport reactions [45], which has repeatedly been used for simulation of fumarolic mineralization [54]. It is noteworthy that both polymorphs of $\mathrm{Zn}_{2}\left(\mathrm{SeO}_{3}\right) \mathrm{Cl}_{2}$ are highly hygroscopic. Their crystal structures are very close to each other and both are based upon the same type of electroneutral $\left[\mathrm{Zn}_{2}\left(\mathrm{SeO}_{3}\right) \mathrm{Cl}_{2}\right]^{0}$ layers formed by $\left(\mathrm{ZnO}_{2} \mathrm{Cl}_{2}\right)$ tetrahedra, $\left(\mathrm{ZnO}_{4} \mathrm{Cl}_{2}\right)$ octahedra, and $\left(\mathrm{SeO}_{3}\right)$ trigonal pyramids (Figure 1a). The $\left(\mathrm{ZnO}_{4} \mathrm{Cl}_{2}\right)$ octahedra share common $\mathrm{O}$ corners to form chains running parallel to $c$ in both polymorphs. Each octahedron shares one $\mathrm{O}-\mathrm{Cl}$ edge with an adjacent $\left(\mathrm{ZnO}_{2} \mathrm{Cl}_{2}\right)$ tetrahedron and one $\mathrm{O}-\mathrm{O}$ edge with $\left(\mathrm{SeO}_{3}\right)$ pyramid, which provide linkage of the chains into two-dimensional layers. The layers are parallel to (010) in sofiite (Figure 1b) and to (100) in the $\beta$-polymorph (Figure 1c). The structures of both modifications may be considered as polytypes, since they are based upon the same type of layers. According to the modern nomenclature, sofiite as $\alpha-\mathrm{Zn}_{2}\left(\mathrm{SeO}_{3}\right) \mathrm{Cl}_{2}$ should be regarded as 2O-polytype (orthorhombic structure with two layers per unit cell), whereas $\beta-\mathrm{Zn}_{2}\left(\mathrm{SeO}_{3}\right) \mathrm{Cl}_{2}$ should be considered as $1 M$-polytype (monoclinic structure with one layer per unit cell). Since the layers in the structures of both polytypes are electroneutral, the linkage between the layers is achieved through the secondary bonds that involve $\mathrm{Cl}^{-}$anions and $\mathrm{Se}^{4+}$ cations (Figure 1).

The lists of bcps found for sofiite and $\beta-\mathrm{Zn}_{2}\left(\mathrm{SeO}_{3}\right) \mathrm{Cl}_{2}$ are given in Tables 2 and 3 , respectively. It can be clearly seen that the interatomic interactions in the two structures can be subdivided into two groups: interactions with $H\left(\mathbf{r}_{\mathbf{c}}\right)<0$ and interactions with $H\left(\mathbf{r}_{\mathbf{c}}\right)>0$. The first kind of interactions 
is observed for the $\mathrm{Se}-\mathrm{O}, \mathrm{Zn}-\mathrm{O}$, and $\mathrm{Zn}-\mathrm{Cl}$ bonds. These interactions correspond to the intralayer bonding and can be characterized as belonging to the intermediate type (since $\nabla^{2} \rho\left(\mathbf{r}_{\mathbf{c}}\right)>0$ for all interactions in the two structures). According to the $\rho\left(\mathbf{r}_{\mathbf{c}}\right)$ values, these bonds can be separated into Se-O bonds $\left(\rho\left(\mathbf{r}_{\mathbf{c}}\right)=0.18-0.20\right.$ a.u. $)$ and $\mathrm{Zn}-\mathrm{X}$ bonds $\left(\rho\left(\mathbf{r}_{\mathbf{c}}\right)=0.02-0.08\right.$ a.u. $)$.

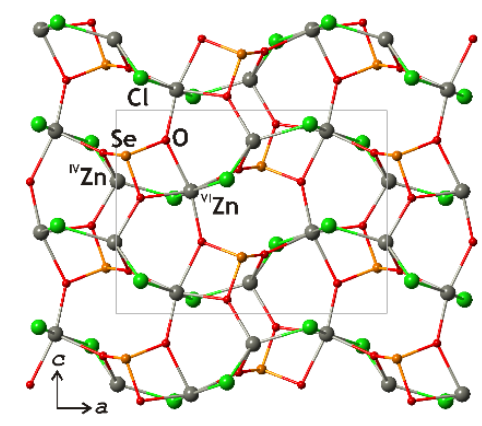

(a)

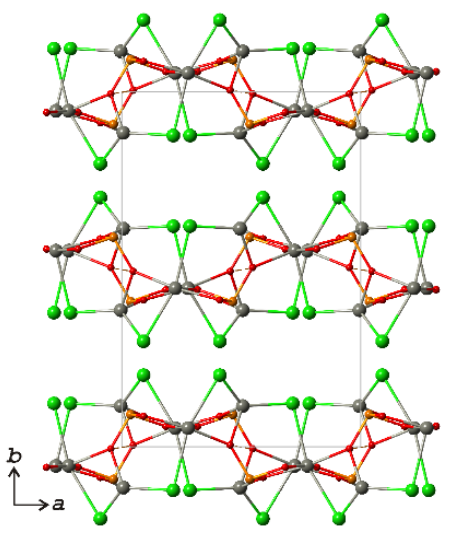

(b)

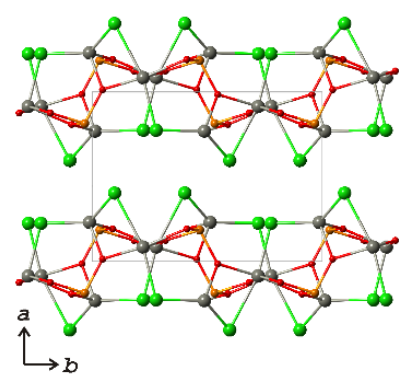

(c)

Figure 1. The crystal structures of the $\mathrm{Zn}_{2}\left(\mathrm{SeO}_{3}\right) \mathrm{Cl}_{2}$ polymorphs: (a) the structure of the $\left[\mathrm{Zn}_{2}\left(\mathrm{SeO}_{3}\right) \mathrm{Cl}_{2}\right]^{0}$ layer in sofiite; (b) the projection of the structure of sofiite parallel to the $c$ axis; (c) the projection of the structure of $\beta-\mathrm{Zn}_{2}\left(\mathrm{SeO}_{3}\right) \mathrm{Cl}_{2}$ parallel to the $c$ axis. Legend: $\mathrm{Zn}, \mathrm{Se}, \mathrm{Cl}$, and $\mathrm{O}$ atoms are shown as gray, orange, green, and red spheres, respectively.

The most interesting are the bcps, for which $\nabla^{2} \rho\left(\mathbf{r}_{\mathbf{c}}\right)>0$ and $H\left(\mathbf{r}_{\mathbf{c}}\right)>0$. These bond paths correspond to the $\mathrm{Se}-\mathrm{Cl}, \mathrm{Cl}-\mathrm{Cl}$, and $\mathrm{O}-\mathrm{O}$ closed-shell interactions, which we shall analyse in more detail. The geometrical environments around the atoms participating in weak closed-shell interactions in sofiite are shown in Figure 2. There are three $\mathrm{Se}-\mathrm{Cl}$ interactions (Figure 2a), from which two interactions (Se-Cl1 and $\mathrm{Se}-\mathrm{Cl} 2)$ are intralayer and one Se-Cl2 interaction is interlayer. The same situation is also observed in $\beta-\mathrm{Zn}_{2}\left(\mathrm{SeO}_{3}\right) \mathrm{Cl}_{2}$ (Figure 3a). In sofiite, the interlayer interaction corresponds to the shortest $\mathrm{Se}-\mathrm{Cl}$ distance of $3.317 \AA$, whereas, in $\beta-\mathrm{Zn}_{2}\left(\mathrm{SeO}_{3}\right) \mathrm{Cl}_{2}$, the respective $\mathrm{Se}-\mathrm{Cl}$ distance is the longest among three $\mathrm{Se}-\mathrm{Cl}$ contacts with its length equal to $3.514 \AA$. Taking into account weak interactions, the coordination of Se atom in both polymorphs can be considered as a distorted trigonal $\left(\mathrm{SeO}_{3} \mathrm{Cl}_{3}\right)$ prism with the $\mathrm{O}_{3}$ and $\mathrm{Cl}_{3}$ triangular bases. The Se-O interactions are more than one order stronger than the Se-Cl interactions. The number of $\mathrm{Cl}-\mathrm{Cl}$ interactions in the two $\mathrm{Zn}_{2}\left(\mathrm{SeO}_{3}\right) \mathrm{Cl}_{2}$ is notably different, despite the fact that the number of symmetrically independent bcps is the same (Tables 2 and 3). The point is that two $\mathrm{Cl}-\mathrm{Cl}$ bcps in sofiite are located on the twofold axes, whereas similar bcps in $\beta-\mathrm{Zn}_{2}\left(\mathrm{SeO}_{3}\right) \mathrm{Cl}_{2}$ are in general positions. In general, the structure of $\beta-\mathrm{Zn}_{2}\left(\mathrm{SeO}_{3}\right) \mathrm{Cl}_{2}$ contains $12 \mathrm{Cl}-\mathrm{Cl}$ bcps per interlayer, whereas the structure of sofiite contains only 8 . The difference results in different coordinations of the $\mathrm{Cl}$ atoms in the structures of the two polymorphs.

The $\mathrm{Cl} 1$ atom (Figure $2 \mathrm{~b}$ ) is linked to two $\mathrm{Zn}$ atoms and participates in three $\mathrm{Cl}-\mathrm{Cl}$ and one $\mathrm{Se}-\mathrm{Cl}$ interactions. The overall coordination of the $\mathrm{Cl1}$ atom can be described as distorted octahedral. From four weak closed-shell interactions, only one $\mathrm{Cl}-\mathrm{Cl}$ interaction has an interlayer character. In $\beta-\mathrm{Zn}_{2}\left(\mathrm{SeO}_{3}\right) \mathrm{Cl}_{2}$, the analogue of the $\mathrm{Cl} 1$ position in sofiite is the $\mathrm{Cl} 2$ site (Figure $3 \mathrm{c}$ ). Its intralayer coordination (by two $\mathrm{Zn}$, one $\mathrm{Se}$, and two $\mathrm{Cl}$ atoms) is very similar to that observed in sofiite. However, there are two interlayer $\mathrm{Cl}-\mathrm{Cl}$ interactions versus one in sofiite. Thus, the total coordination of the $\mathrm{Cl} 2$ site in the $\beta$-polymorph is sevenfold. The coordination of the $\mathrm{Cl} 2$ site in sofiite is shown in Figure 2c. There are two intralayer $\mathrm{Cl}-\mathrm{Zn}$ bonds and one intralayer $\mathrm{Cl}-\mathrm{Se}$ interaction. The interlayer interactions are characterized by one $\mathrm{Cl}-\mathrm{Se}$ and one $\mathrm{Cl}-\mathrm{Cl}$ bond paths. The situation in $\beta-\mathrm{Zn}_{2}\left(\mathrm{SeO}_{3}\right) \mathrm{Cl}_{2}$ is again different (Figure 3b). The number of intralayer interactions is the same as in sofiite, but there are 
three interlayer interactions, one $\mathrm{Cl}-\mathrm{Se}$ and two $\mathrm{Cl}-\mathrm{Cl}$. In total, the coordination of the $\mathrm{Cl} 1$ site in the $\beta$-polymorph is sixfold versus fivefold in sofiite.

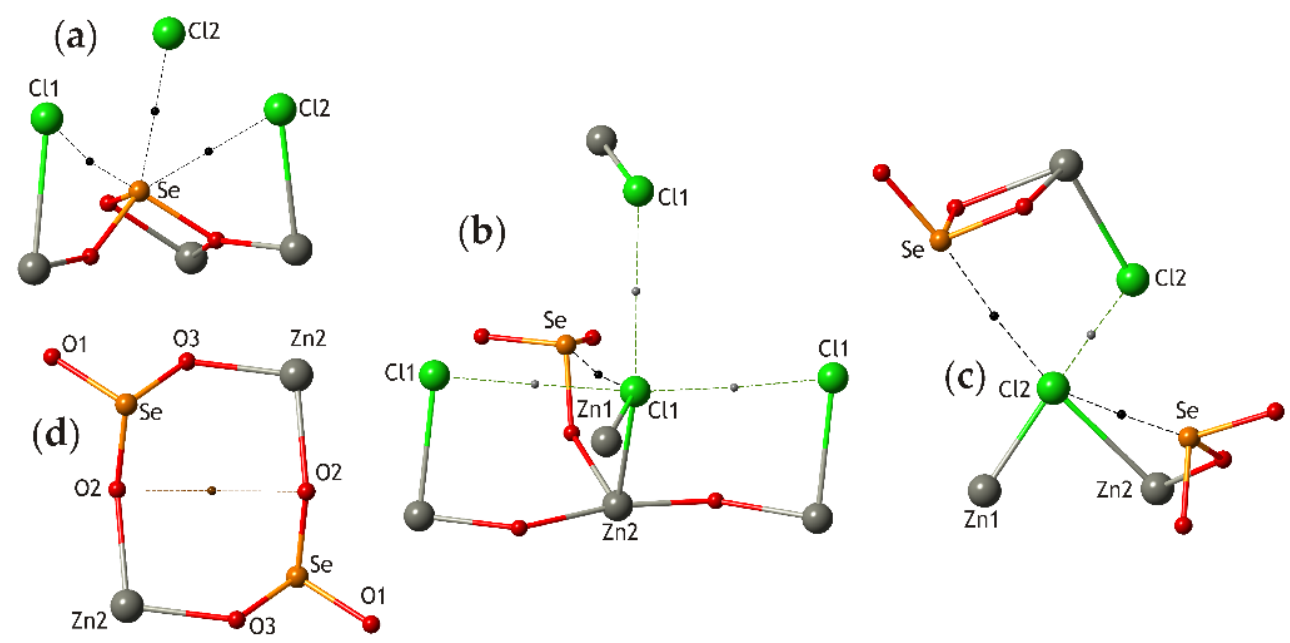

Figure 2. Geometrical environment of bond critical points of weak closed-shell interactions in sofiite, $\alpha-\mathrm{Zn}_{2}\left(\mathrm{SeO}_{3}\right) \mathrm{Cl}_{2}$ : (a) the bcps around the Se site; (b) the bcps around the Cl1 site; (c) the bcps around the $\mathrm{Cl} 2$ site; (d) bcp between the $\mathrm{O} 2$ and $\mathrm{O} 2$ atoms. Legend as in Figure 1.

Table 2. Bond critical points in the crystal structure of sofiite, $\alpha-\mathrm{Zn}_{2}\left(\mathrm{SeO}_{3}\right) \mathrm{Cl}_{2}$, and their properties.

\begin{tabular}{|c|c|c|c|c|c|c|c|c|}
\hline $\mathbf{A}_{1}$ & $\mathbf{A}_{2}$ & $d[\AA ̊]$ & $\rho\left(\mathrm{r}_{\mathrm{c}}\right)$ & $\nabla^{2} \rho\left(\mathrm{r}_{\mathrm{c}}\right)$ & $G\left(\mathrm{r}_{\mathrm{c}}\right)$ & $V\left(\mathrm{r}_{\mathrm{c}}\right)$ & $H\left(\mathbf{r}_{\mathrm{c}}\right)$ & BD \\
\hline \multicolumn{9}{|c|}{ Se-O and $\mathrm{Zn}-X$ bonds $(X=\mathrm{O}, \mathrm{Cl})$} \\
\hline Se & $\mathrm{O} 1$ & 1.688 & 0.1940 & 0.4591 & 0.2357 & -0.3566 & -0.1209 & -0.624 \\
\hline Se & O3 & 1.697 & 0.1922 & 0.4144 & 0.2247 & -0.3458 & -0.1211 & -0.630 \\
\hline Se & $\mathrm{O} 2$ & 1.701 & 0.1883 & 0.4108 & 0.2196 & -0.3364 & -0.1168 & -0.620 \\
\hline Zn1 & O1 & 1.993 & 0.0758 & 0.3908 & 0.1109 & -0.1242 & -0.0133 & -0.175 \\
\hline Zn1 & $\mathrm{O} 2$ & 2.057 & 0.0667 & 0.3232 & 0.0908 & -0.1007 & -0.0099 & -0.148 \\
\hline Zn1 & $\mathrm{Cl} 2$ & 2.205 & 0.0784 & 0.2664 & 0.0849 & -0.1033 & -0.0184 & -0.235 \\
\hline Zn1 & $\mathrm{Cl1}$ & 2.244 & 0.0732 & 0.2346 & 0.0746 & -0.0905 & -0.0159 & -0.217 \\
\hline $\mathrm{Zn} 2$ & O1 & 1.993 & 0.0781 & 0.3984 & 0.1144 & -0.1292 & -0.0148 & -0.190 \\
\hline $\mathrm{Zn} 2$ & $\mathrm{O} 2$ & 2.115 & 0.0558 & 0.2667 & 0.0717 & -0.0766 & -0.0049 & -0.088 \\
\hline $\mathrm{Zn} 2$ & $\mathrm{O} 3$ & 1.955 & 0.0837 & 0.4391 & 0.1267 & -0.1435 & -0.0168 & -0.201 \\
\hline $\mathrm{Zn} 2$ & $\mathrm{O} 3$ & 2.147 & 0.0551 & 0.2511 & 0.0687 & -0.0747 & -0.0060 & -0.109 \\
\hline $\mathrm{Zn} 2$ & $\mathrm{Cl} 2$ & 2.685 & 0.0298 & 0.0783 & 0.0220 & -0.0245 & -0.0025 & -0.084 \\
\hline $\mathrm{Zn} 2$ & $\mathrm{Cl1}$ & 2.753 & 0.0256 & 0.0652 & 0.0180 & -0.0197 & -0.0017 & -0.066 \\
\hline \multicolumn{9}{|c|}{$\mathrm{Se}-\mathrm{Cl}, \mathrm{Cl}-\mathrm{Cl}$, and $\mathrm{O}-\mathrm{O}$ interactions } \\
\hline Se & $\mathrm{Cl} 2$ & 3.317 & 0.0121 & 0.0349 & 0.0078 & -0.0069 & 0.0009 & 0.074 \\
\hline Se & $\mathrm{Cl} 2$ & 3.444 & 0.0103 & 0.0312 & 0.0069 & -0.0060 & 0.0009 & 0.087 \\
\hline Se & $\mathrm{Cl1}$ & 3.533 & 0.0080 & 0.0268 & 0.0057 & -0.0046 & 0.0011 & 0.138 \\
\hline $\mathrm{Cl} 1$ & $\mathrm{Cl} 1$ & 3.898 & 0.0039 & 0.0143 & 0.0028 & -0.0021 & 0.0007 & 0.179 \\
\hline $\mathrm{Cl} 1$ & $\mathrm{Cl} 1$ & 3.955 & 0.0029 & 0.0115 & 0.0022 & -0.0015 & 0.0007 & 0.241 \\
\hline $\mathrm{Cl} 2$ & $\mathrm{Cl} 2$ & 3.567 & 0.0071 & 0.0208 & 0.0046 & -0.0041 & 0.0005 & 0.070 \\
\hline $\mathrm{O} 2$ & $\mathrm{O} 2$ & 3.362 & 0.0055 & 0.0181 & 0.0038 & 0.0030 & 0.0008 & 0.145 \\
\hline
\end{tabular}




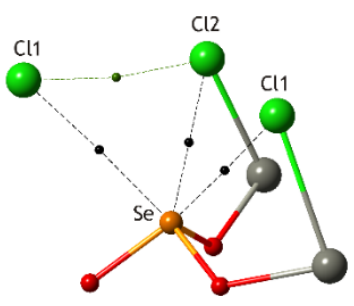

(a)

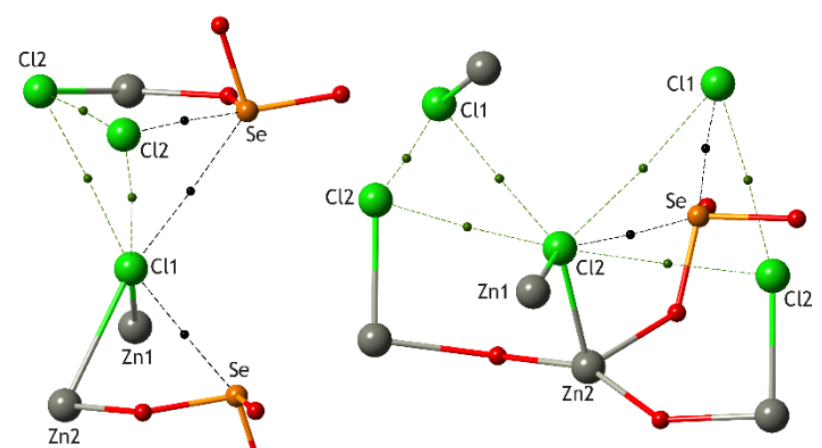

(b)

(c)

Figure 3. Geometrical environment of bond critical points of weak closed-shell interactions in $\beta-\mathrm{Zn}_{2}\left(\mathrm{SeO}_{3}\right) \mathrm{Cl}_{2}$ : (a) The bcps around the Se site; (b) The bcps around the Cl1 site; (c) The bcps around the $\mathrm{Cl} 2$ site. Legend as in Figure 1.

Table 3. Bond critical points in the crystal structure of $\beta-\mathrm{Zn}_{2}\left(\mathrm{SeO}_{3}\right) \mathrm{Cl}_{2}$ and their properties.

\begin{tabular}{|c|c|c|c|c|c|c|c|c|}
\hline $\mathbf{A}_{1}$ & $\mathbf{A}_{2}$ & $d[\AA ̊]$ & $\rho\left(\mathrm{r}_{\mathrm{c}}\right)$ & $\nabla^{2} \rho\left(\mathrm{r}_{\mathrm{c}}\right)$ & $G\left(\mathrm{r}_{\mathrm{c}}\right)$ & $V\left(\mathrm{r}_{\mathrm{c}}\right)$ & $H\left(r_{c}\right)$ & BD \\
\hline \multicolumn{9}{|c|}{ Se- $\mathrm{O}$ and $\mathrm{Zn}-X$ bonds $(X=\mathrm{O}, \mathrm{Cl})$} \\
\hline Se1 & $\mathrm{O} 3$ & 1.703 & 0.1901 & 0.3856 & 0.2163 & -0.3361 & -0.1198 & -0.630 \\
\hline Se1 & O1 & 1.707 & 0.1879 & 0.3797 & 0.2123 & -0.3297 & -0.1174 & -0.625 \\
\hline Se1 & $\mathrm{O} 2$ & 1.715 & 0.1836 & 0.3736 & 0.2065 & -0.3196 & -0.1131 & -0.616 \\
\hline Zn2 & O1 & 2.126 & 0.0574 & 0.2672 & 0.0733 & -0.0798 & -0.0065 & -0.113 \\
\hline Zn1 & O1 & 1.983 & 0.0779 & 0.4009 & 0.1147 & -0.1291 & -0.0144 & -0.185 \\
\hline Zn1 & $\mathrm{O} 2$ & 2.031 & 0.0702 & 0.3492 & 0.0984 & -0.1096 & -0.0112 & -0.160 \\
\hline Zn1 & $\mathrm{Cl1}$ & 2.222 & 0.0761 & 0.2519 & 0.0801 & -0.0972 & -0.0171 & -0.225 \\
\hline Zn1 & $\mathrm{Cl} 2$ & 2.226 & 0.0751 & 0.2519 & 0.0795 & -0.0961 & -0.0166 & -0.221 \\
\hline $\mathrm{Zn} 2$ & $\mathrm{O} 3$ & 2.008 & 0.0737 & 0.3733 & 0.1056 & -0.1178 & -0.0122 & -0.166 \\
\hline $\mathrm{Zn} 2$ & $\mathrm{O} 2$ & 2.049 & 0.0663 & 0.3304 & 0.0914 & -0.1002 & -0.0088 & -0.133 \\
\hline $\mathrm{Zn} 2$ & $\mathrm{O} 3$ & 2.150 & 0.0546 & 0.2470 & 0.0676 & -0.0735 & -0.0059 & -0.108 \\
\hline $\mathrm{Zn} 2$ & $\mathrm{Cl} 2$ & 2.430 & 0.0487 & 0.1555 & 0.0445 & -0.0501 & -0.0056 & -0.115 \\
\hline Zn2 & $\mathrm{Cl1}$ & 2.765 & 0.0250 & 0.0649 & 0.0179 & -0.0196 & -0.0017 & -0.068 \\
\hline \multicolumn{9}{|c|}{$\mathrm{Se}-\mathrm{Cl}, \mathrm{Cl}-\mathrm{Cl}$, and $\mathrm{O}-\mathrm{O}$ interactions } \\
\hline Se1 & $\mathrm{Cl} 2$ & 3.382 & 0.0106 & 0.0343 & 0.0075 & -0.0064 & 0.0009 & 0.085 \\
\hline Se1 & $\mathrm{Cl} 1$ & 3.482 & 0.0096 & 0.0297 & 0.0065 & -0.0055 & 0.0010 & 0.104 \\
\hline Se1 & $\mathrm{Cl1}$ & 3.514 & 0.0085 & 0.0252 & 0.0053 & -0.0044 & 0.0009 & 0.106 \\
\hline $\mathrm{Cl} 1$ & $\mathrm{Cl} 2$ & 3.534 & 0.0079 & 0.0225 & 0.0051 & -0.0046 & 0.0005 & 0.063 \\
\hline $\mathrm{Cl} 1$ & $\mathrm{Cl} 2$ & 3.956 & 0.0029 & 0.0113 & 0.0021 & -0.0014 & 0.0007 & 0.241 \\
\hline $\mathrm{Cl} 2$ & $\mathrm{Cl} 2$ & 3.869 & 0.0041 & 0.0151 & 0.0030 & -0.0022 & 0.0008 & 0.195 \\
\hline $\mathrm{O} 2$ & $\mathrm{O} 2$ & 3.470 & 0.0048 & 0.0155 & 0.0032 & -0.0026 & 0.0006 & 0.125 \\
\hline
\end{tabular}

In both polymorphs, there is a bcp between the two $\mathrm{O}$ atoms located in the middle of the eight-membered atomic ring (Figure 2d). This bcp is located in the inversion center and corresponds to a very weak closed-shell interaction.

The higher relative number of bcps in $\beta-\mathrm{Zn}_{2}\left(\mathrm{SeO}_{3}\right) \mathrm{Cl}_{2}$ compared to sofiite might be related to the higher stability of the $\beta$-polymorph. Its physical density, $3.68 \mathrm{~g} \cdot \mathrm{cm}^{-3}$ is slightly higher than that of sofiite, $3.65 \mathrm{~g} \cdot \mathrm{cm}^{-3}$, which manifests the higher efficiency of layer packing, which, in turn, may lead to the formation of more interlayer interactions, thus stabilizing the $\beta$-polymorph. It is noteworthy that, among the closed-shell interactions in the two polymorphs, the $\mathrm{Se}-\mathrm{Cl}$ interactions are stronger than others, pointing out their important role in the linkage of the $\left[\mathrm{Zn}_{2}\left(\mathrm{SeO}_{3}\right) \mathrm{Cl}_{2}\right]^{0}$ in the structures. Nevertheless, the $\mathrm{Cl}-\mathrm{Cl}$ interactions are also of importance, providing additional contributions to the structural stability. 


\section{2. $\mathrm{Cu}_{5} \mathrm{O}_{2}\left(\mathrm{SeO}_{3}\right)_{2} \mathrm{Cl}_{2}$ Polymorphs}

In fact, $\alpha-\mathrm{Cu}_{5} \mathrm{O}_{2}\left(\mathrm{SeO}_{3}\right)_{2} \mathrm{Cl}_{2}$ was the first selenite chloride reported by Galy et al. back in 1979 [55]. Its dark-brown crystals were prepared by the chemical vapor transport reactions method. In 1999, it was described by Vergasova et al. [16] as a natural mineral species from fumaroles of the Great fissure Tolbachik eruption (Kamchatka, Russia). In 2006, Vergasova et al. [20] described another natural polymorph of $\mathrm{Cu}_{5} \mathrm{O}_{2}\left(\mathrm{SeO}_{3}\right)_{2} \mathrm{Cl}_{2}$, which was named parageorgbokiite in order to recognize its chemical similarity to georgbokiite. It is noteworthy that, in contrast to georgbokiite, the crystals of parageorgbokiite are green and thus the two polymorphs can easily be distinguished. The crystal structures of georgbokiite and parageorgbokiite are closely related and the best way to understand these relations are to describe them in terms of structural units based upon oxocentered tetrahedra formed around 'additional' $\mathrm{O}$ atoms not bonded to $\mathrm{Se}^{4+}$ cations. This approach was first proposed in 1968 [56] and recently developed into a coherent crystal chemical theory (see [57,58] for reviews and historical remarks). In general, description of certain crystal structures in terms of anion-centered coordination polyhedra became more popular over the years, in part due to the recent reports on interesting structural and physical properties and mineralogical importance of antiperovskites, i.e., materials with structures based upon anion-centered octahedra [59-66].

In the crystal structures of both polymorphs of $\mathrm{Cu}_{5} \mathrm{O}_{2}\left(\mathrm{SeO}_{3}\right)_{2} \mathrm{Cl}_{2}$, there are additional $\mathrm{O}$ atoms not bonded to Se and tetrahedrally coordinated by four $\mathrm{Cu}$ atoms thus forming $\left(\mathrm{OCu}_{4}\right)$ oxocentered tetrahedra. In both structures, $\left(\mathrm{OCu}_{4}\right)$ tetrahedra share $\mathrm{Cu}-\mathrm{Cu}$ edges and $\mathrm{Cu}$ corners to form $\left[\mathrm{O}_{2} \mathrm{Cu}_{5}\right]$ chains shown in Figure 4a. The $\left(\mathrm{SeO}_{3}\right)$ groups are attached to $\left(\mathrm{OCu}_{4}\right)$ tetrahedra in a face-to-face fashion $[67,68]$, which means that the triangular bases of both units are parallel to each other and have the same orientation. The complex 1-dimensional structural units with the composition $\left\{\left[\mathrm{O}_{2} \mathrm{Cu}_{5}\right]\left(\mathrm{SeO}_{3}\right)_{2}\right\}^{2+}$ shown in Figure $4 \mathrm{~b}$ are the basic structural modules for both polymorphs and it is the mode of their combination that generates the structural difference.

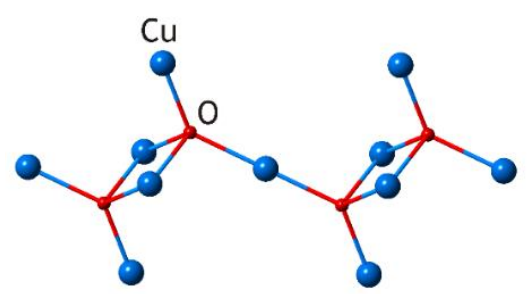

(a)

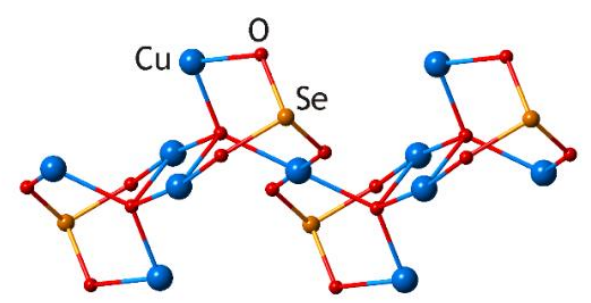

(b)

Figure 4. The basic structural module for the crystal structures of the $\mathrm{Cu}_{5} \mathrm{O}_{2}\left(\mathrm{SeO}_{3}\right)_{2} \mathrm{Cl}_{2}$ polymorphs (georgbokiite and parageorgbokiite): (a) the $\left[\mathrm{O}_{2} \mathrm{Cu}_{5}\right]$ chain formed by alternating edge- and corner-sharing $\left(\mathrm{OCu}_{4}\right)$ tetrahedra; $(\mathbf{b})$ the $\left\{\left[\mathrm{O}_{2} \mathrm{Cu}_{5}\right]\left(\mathrm{SeO}_{3}\right)_{2}\right\}$ 1-dimensional module formed by the face-to-face attachment of $\left(\mathrm{SeO}_{3}\right)$ groups to $\left(\mathrm{OCu}_{4}\right)$ tetrahedra.

Figure 5 shows a successive (step-by-step) construction of the crystal structure of georgbokiite, $\alpha-\mathrm{Cu}_{5} \mathrm{O}_{2}\left(\mathrm{SeO}_{3}\right)_{2} \mathrm{Cl}_{2}$, if viewed in terms of anion-centered tetrahedra. The $\left[\mathrm{O}_{2} \mathrm{Cu}_{5}\right]$ chains are running parallel to the $c$ axis and grouped into layers parallel to the (100) plane (Figure 5a). The $\left(\mathrm{SeO}_{3}\right)$ groups are attached to the chains and are also responsible for the linkage of the $\left\{\left[\mathrm{O}_{2} \mathrm{Cu}_{5}\right]\left(\mathrm{SeO}_{3}\right)_{2}\right\}^{2+}$ in the (100) and (010) directions through the formation of the $\mathrm{Cu}-\mathrm{O}$ bonds (Figure 5b). The metal-oxide bonding network based upon the $\mathrm{Cu}-\mathrm{O}$ and $\mathrm{Se}-\mathrm{O}$ bonds contains the strongest chemical bonds in the structure. It can be seen, however, that this network possesses 1-dimensional channels parallel to (001) (i.e., the direction of extension of the $\left[\mathrm{O}_{2} \mathrm{Cu}_{5}\right]$ chains) and these channels are occupied by $\mathrm{Cl}^{-}$anions (Figure 5c). These channels are also remarkable by the fact that they provide spatial localization of the weak closed-shell interactions in the crystal structure (Figure 5d). 
(a)

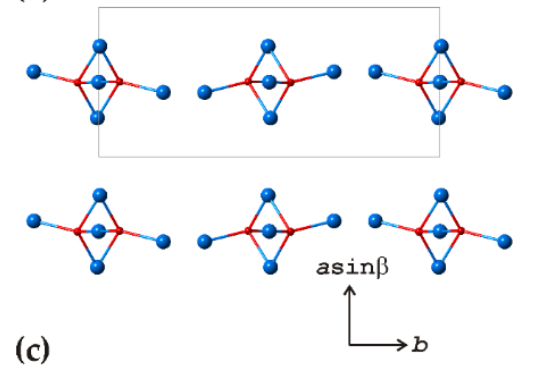

(c)

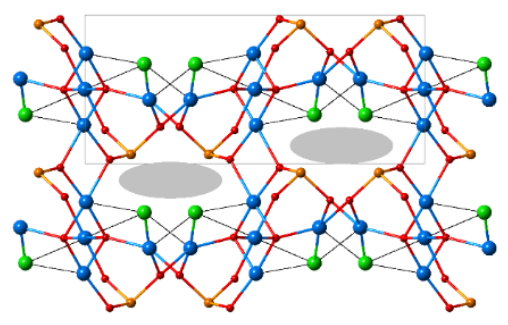

(b)

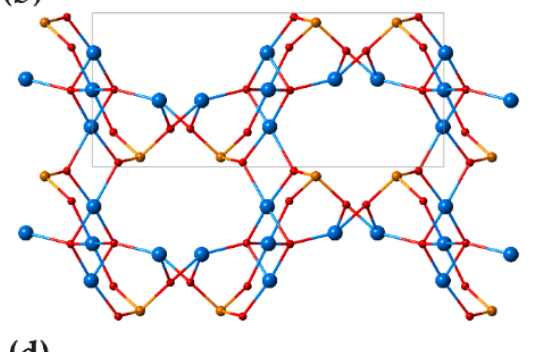

(d)

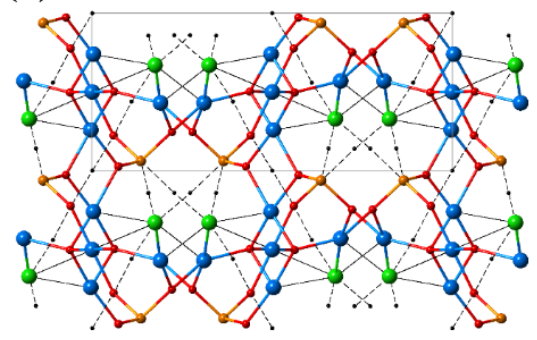

Figure 5. The scheme of successive (step-by-step) construction of the crystal structure of georgbokiite, $\alpha-\mathrm{Cu}_{5} \mathrm{O}_{2}\left(\mathrm{SeO}_{3}\right)_{2} \mathrm{Cl}_{2}$ : (a) the arrangement of the $\left[\mathrm{O}_{2} \mathrm{Cu}_{5}\right]$ chains of edge- and corner-sharing $\left(\mathrm{OCu}_{4}\right)$ tetrahedra; (b) the metal-oxide bonding network of the $\mathrm{Cu}-\mathrm{O}$ and Se-O bonds; (c) the structure projection showing the positions of the $\mathrm{Cl}$ atoms and the location of extended channels parallel to [001] (shown in gray); (d) the location of bcps corresponding to weak closed-shell interactions. See text for details. Legend: $\mathrm{Cu}, \mathrm{Se}, \mathrm{O}$, and $\mathrm{Cl}$ atoms are shown as blue, orange, red, and green spheres, respectively. Small black spheres indicate the positions of bcps.

The mode of linkage of the basic structural modules in the structure of parageorgbokiite, $\beta-\mathrm{Cu}_{5} \mathrm{O}_{2}\left(\mathrm{SeO}_{3}\right)_{2} \mathrm{Cl}_{2}$, is different, which is illustrated in Figure 6.

In contrast to georgbokiite, the $\left[\mathrm{O}_{2} \mathrm{Cu}_{5}\right]$ chains in parageorgbokiite have different relative orientations (Figure 6a) and are parallel to the $a$ axis. Their linkage through $\left(\mathrm{SeO}_{3}\right)$ groups (attached to the $\left(\mathrm{OCu}_{4}\right)$ tetrahedra in the face-to-face fashion) results in the formation of a 3-dimensional framework of relatively strong bonds (Figure 6b) with channels occupied by $\mathrm{Cl}^{-}$anions (Figure 6c) and hosting the bcps corresponding to weak closed-shell interactions (Figure 6d).

Tables 4 and 5 provide lists of bcps found for georgbokiite and parageorgbokiite, respectively. According to their properties, all interatomic interactions in the two minerals can be classified into three groups:

(1) the $\mathrm{Cu}-\mathrm{O}, \mathrm{Cu}-\mathrm{Cl}$ and Se-O interactions with $\nabla^{2} \rho\left(\mathbf{r}_{\mathbf{c}}\right)>0$ and $H\left(\mathbf{r}_{\mathbf{c}}\right)<0$ (intermediate bonding interactions);

(2) the $\mathrm{Cu}-\mathrm{O}$ and $\mathrm{Cu}-\mathrm{Cl}$ interactions with $\nabla^{2} \rho\left(\mathbf{r}_{\mathbf{c}}\right)>0$ and $H\left(\mathbf{r}_{\mathbf{c}}\right)>0$ (closed-shell interactions); the $\mathrm{Cu} 3-\mathrm{Cl}$ interaction $(2.739 \AA)$ deserves special attention as this interaction lies exactly on the border between intermediate and closed-shell interactions $\left(H\left(\mathbf{r}_{\mathbf{c}}\right)=0\right)$;

(3) the closed-shell Se-Cl, Cl-Cl, and Cl-O interactions with $\nabla^{2} \rho\left(\mathbf{r}_{\mathbf{c}}\right)>0$ and $H\left(\mathbf{r}_{\mathbf{c}}\right)>0$.

The appearance of the second group of interactions (which is absent in the $\mathrm{Zn}_{2}\left(\mathrm{SeO}_{3}\right) \mathrm{Cl}_{2}$ polymorphs) is due to the Jahn-Teller distortion of $\mathrm{Cu}^{2+}$ coordination [69], which results in the splitting of $\mathrm{Cu}-X$ interactions $(X=\mathrm{O}, \mathrm{Cl})$ into short and long bonds. It is noteworthy that the empirical bond-valence theory [70] would make no distinction between the different long $\mathrm{Cu}-\mathrm{X}$ bonds, whereas the data given in Tables 4 and 5 indicate that the AIM theory classifies them into closed-shell and intermediate interactions (taking into account the conditional character of the adopted classification (see Section 2)). In particular, for the $\mathrm{Cu}-\mathrm{Cl}$ bonds, the border between the two types of interactions corresponds to the $\mathrm{Cu}-\mathrm{Cl}$ distance of $2.739 \AA$. It is of interest that the $\rho\left(\mathrm{r}_{\mathrm{c}}\right)$ for the closed-shell $\mathrm{Cu}-X$ interactions is of the same order as for other closed-shell interactions in the two structures. 
Table 4. Bond critical points in the crystal structure of $\alpha-\mathrm{Cu}_{5} \mathrm{O}_{2}\left(\mathrm{SeO}_{3}\right)_{2} \mathrm{Cl}_{2}$ and their properties.

\begin{tabular}{ccccccccc}
\hline $\mathbf{A}_{\mathbf{1}}$ & $\mathbf{A}_{\mathbf{2}}$ & $\boldsymbol{d}[\mathbf{A}]$ & $\boldsymbol{\rho}\left(\mathbf{r}_{\mathbf{c}}\right)$ & $\nabla^{\mathbf{2}} \boldsymbol{\rho}\left(\mathbf{r}_{\mathbf{c}}\right)$ & $G\left(\mathbf{r}_{\mathbf{c}}\right)$ & $\boldsymbol{V}\left(\mathbf{r}_{\mathbf{c}}\right)$ & $\boldsymbol{H}\left(\mathbf{r}_{\mathbf{c}}\right)$ & $\mathbf{B D}$ \\
\hline $\mathrm{Cu} 1$ & $\mathrm{O} 1$ & 1.923 & 0.0979 & 0.3812 & 0.1339 & -0.1725 & -0.0386 & -0.394 \\
$\mathrm{Cu} 1$ & $\mathrm{O} 4$ & 1.962 & 0.0855 & 0.3506 & 0.1189 & -0.1501 & -0.0312 & -0.365 \\
$\mathrm{Cu} 1$ & $\mathrm{O} 4$ & 2.046 & 0.0694 & 0.2766 & 0.0922 & -0.1153 & -0.0231 & -0.333 \\
$\mathrm{Cu} 1$ & $\mathrm{C} 1$ & 2.282 & 0.0682 & 0.1701 & 0.0658 & -0.0890 & -0.0232 & -0.340 \\
$\mathrm{Cu} 1$ & $\mathrm{Cl}$ & 2.570 & 0.0371 & 0.1248 & 0.0352 & -0.0392 & -0.0040 & -0.108 \\
$\mathrm{Cu} 2$ & $\mathrm{O} 2$ & 1.944 & 0.0877 & 0.3727 & 0.1248 & -0.1564 & -0.0316 & -0.360 \\
$\mathrm{Cu} 2$ & $\mathrm{O} 1$ & 1.971 & 0.0857 & 0.3284 & 0.1144 & -0.1467 & -0.0323 & -0.377 \\
$\mathrm{Cu} 2$ & $\mathrm{Cl}$ & 2.954 & 0.0164 & 0.0608 & 0.0138 & -0.0123 & 0.0015 & 0.091 \\
$\mathrm{Cu} 3$ & $\mathrm{O} 2$ & 1.989 & 0.0786 & 0.3254 & 0.1089 & -0.1364 & -0.0275 & -0.350 \\
$\mathrm{Cu} 3$ & $\mathrm{O} 1$ & 1.956 & 0.0911 & 0.3433 & 0.1214 & -0.1570 & -0.0356 & -0.391 \\
$\mathrm{Cu} 3$ & $\mathrm{O} 1$ & 1.952 & 0.0935 & 0.3464 & 0.1238 & -0.1611 & -0.0373 & -0.399 \\
$\mathrm{Cu} 3$ & $\mathrm{O} 3$ & 2.024 & 0.0723 & 0.2917 & 0.0973 & -0.1217 & -0.0244 & -0.337 \\
$\mathrm{Cu} 3$ & $\mathrm{O} 2$ & 2.430 & 0.0283 & 0.1314 & 0.0327 & -0.0326 & 0.0001 & 0.004 \\
$\mathrm{Cu} 3$ & $\mathrm{C} 1$ & 2.739 & 0.0254 & 0.0915 & 0.0229 & -0.0229 & 0.0000 & 0.000 \\
$\mathrm{Se}$ & $\mathrm{O} 2$ & 1.674 & 0.1998 & 0.4741 & 0.2453 & -0.3721 & -0.1268 & -0.635 \\
$\mathrm{Se}$ & $\mathrm{O} 3$ & 1.709 & 0.1870 & 0.3738 & 0.2105 & -0.3275 & -0.1170 & -0.626 \\
$\mathrm{Se}$ & $\mathrm{O} 4$ & 1.724 & 0.1820 & 0.3276 & 0.1952 & -0.3084 & -0.1132 & -0.622 \\
$\mathrm{Se}$ & $\mathrm{Cl}$ & 3.310 & 0.0129 & 0.0378 & 0.0083 & -0.0072 & 0.0011 & 0.085 \\
$\mathrm{Se}$ & $\mathrm{C} 1$ & 3.544 & 0.0086 & 0.0244 & 0.0053 & -0.0045 & 0.0008 & 0.093 \\
$\mathrm{Cl}$ & $\mathrm{O} 2$ & 3.216 & 0.0113 & 0.0358 & 0.0082 & -0.0074 & 0.0008 & 0.071 \\
$\mathrm{O} 2$ & $\mathrm{O} 2$ & 3.972 & 0.0083 & 0.0297 & 0.0062 & -0.0050 & 0.0012 & 0.145 \\
\hline
\end{tabular}

Table 5. Bond critical points in the crystal structure of $\beta-\mathrm{Cu}_{5} \mathrm{O}_{2}\left(\mathrm{SeO}_{3}\right)_{2} \mathrm{Cl}_{2}$ and their properties.

\begin{tabular}{ccccccccc}
\hline $\mathbf{A}_{\mathbf{1}}$ & $\mathbf{A}_{\mathbf{2}}$ & $\boldsymbol{d}[\mathbf{A}]$ & $\boldsymbol{\rho}\left(\mathbf{r}_{\mathbf{c}}\right)$ & $\nabla^{2} \boldsymbol{\rho}\left(\mathbf{r}_{\mathbf{c}}\right)$ & $G\left(\mathbf{r}_{\mathbf{c}}\right)$ & $\boldsymbol{V}\left(\mathbf{r}_{\mathbf{c}}\right)$ & $H_{\left(\mathbf{r}_{\mathbf{c}}\right)}$ & $\mathbf{B D}$ \\
\hline $\mathrm{Cu} 1$ & $\mathrm{O} 1$ & 1.919 & 0.0976 & 0.3890 & 0.1350 & -0.1727 & -0.0377 & -0.386 \\
$\mathrm{C} 11$ & $\mathrm{O} 2$ & 1.966 & 0.0824 & 0.3500 & 0.1164 & -0.1453 & -0.0289 & -0.351 \\
$\mathrm{Cu} 1$ & $\mathrm{O} 3$ & 1.969 & 0.0834 & 0.3406 & 0.1153 & -0.1455 & -0.0302 & -0.362 \\
$\mathrm{C} 11$ & $\mathrm{C} 1$ & 2.268 & 0.0706 & 0.1716 & 0.0676 & -0.0923 & -0.0247 & -0.350 \\
$\mathrm{Cu} 1$ & $\mathrm{O} 4$ & 2.944 & 0.0096 & 0.0425 & 0.0081 & -0.0056 & 0.0025 & 0.260 \\
$\mathrm{Cu} 1$ & $\mathrm{Cl}$ & 3.185 & 0.0096 & 0.0392 & 0.0079 & -0.0060 & 0.0019 & 0.198 \\
$\mathrm{Cu} 2$ & $\mathrm{O} 1$ & 1.929 & 0.0944 & 0.3815 & 0.1314 & -0.1675 & -0.0361 & -0.382 \\
$\mathrm{Cu} 2$ & $\mathrm{O} 4$ & 1.974 & 0.0823 & 0.3329 & 0.1128 & -0.1425 & -0.0297 & -0.361 \\
$\mathrm{Cu} 3$ & $\mathrm{O} 1$ & 1.945 & 0.0934 & 0.3585 & 0.1260 & -0.1625 & -0.0365 & -0.391 \\
$\mathrm{Cu} 3$ & $\mathrm{O} 2$ & 1.961 & 0.0832 & 0.3576 & 0.1187 & -0.1480 & -0.0293 & -0.352 \\
$\mathrm{Cu} 3$ & $\mathrm{O} 1$ & 1.975 & 0.0885 & 0.3237 & 0.1158 & -0.1506 & -0.0348 & -0.393 \\
$\mathrm{Cu} 3$ & $\mathrm{O} 3$ & 2.057 & 0.0672 & 0.2650 & 0.0881 & -0.1099 & -0.0218 & -0.324 \\
$\mathrm{Cu} 3$ & $\mathrm{O} 4$ & 2.399 & 0.0311 & 0.1409 & 0.0363 & -0.0374 & -0.0011 & -0.035 \\
$\mathrm{Cu} 3$ & $\mathrm{Cl}$ & 2.705 & 0.0283 & 0.0977 & 0.0254 & -0.0264 & -0.0010 & -0.035 \\
$\mathrm{Se}$ & $\mathrm{O} 4$ & 1.675 & 0.2000 & 0.4610 & 0.2428 & -0.3704 & -0.1276 & -0.638 \\
$\mathrm{Se}$ & $\mathrm{O} 3$ & 1.713 & 0.1850 & 0.3654 & 0.2061 & -0.3208 & -0.1147 & -0.620 \\
$\mathrm{Se}$ & $\mathrm{O} 2$ & 1.724 & 0.1813 & 0.3406 & 0.1971 & -0.3091 & -0.1120 & -0.618 \\
$\mathrm{Se}$ & $\mathrm{Cl}$ & 3.300 & 0.0133 & 0.0408 & 0.0093 & -0.0083 & 0.0010 & 0.075 \\
$\mathrm{Se}$ & $\mathrm{Cl}$ & 3.327 & 0.0123 & 0.0357 & 0.0078 & -0.0067 & 0.0011 & 0.089 \\
$\mathrm{Cl}$ & $\mathrm{O} 2$ & 3.321 & 0.0097 & 0.0278 & 0.0065 & -0.0060 & 0.0005 & 0.052 \\
$\mathrm{Cl}$ & $\mathrm{Cl}$ & 3.501 & 0.0104 & 0.0284 & 0.0068 & -0.0065 & 0.0003 & 0.029 \\
$\mathrm{Cl}$ & $\mathrm{Cl}$ & 3.810 & 0.0046 & 0.0158 & 0.0032 & -0.0025 & 0.0007 & 0.152 \\
\hline & & & & & & & &
\end{tabular}

The configuration of closed-shell interactions inside the channels in the crystal structures of the $\mathrm{Cu}_{5} \mathrm{O}_{2}\left(\mathrm{SeO}_{3}\right)_{2} \mathrm{Cl}_{2}$ polymorphs is shown in Figure 7. In georgbokiite (Figure 7a), the channels are more compact and have $\left(\mathrm{SeO}_{3}\right)$ groups on one side and $\mathrm{Cl}^{-}$anions on another, each Se and each $\mathrm{Cl}$ atom participates in two $\mathrm{Se}-\mathrm{Cl}$ interactions, and there are no $\mathrm{Cl}-\mathrm{Cl}$ interactions. In contrast, in parageorgbokiite (Figure $7 \mathrm{~b}$ ), the channels are larger and have both $\left(\mathrm{SeO}_{3}\right)$ groups and $\mathrm{Cl}^{-}$anions on both sides. Each Se atom participates in two Se-Cl interactions, whereas each $\mathrm{Cl}$ atom participates in two $\mathrm{Se}-\mathrm{Cl}$, two $\mathrm{Cl}-\mathrm{Cl}$ and one $\mathrm{Cl}-\mathrm{O}$ interactions. The structure of the channels in the two polymorphs 
is therefore remarkably different, which can be explained by the different arrangements of basic structural modules.

The more open character of the crystal structure of parageorgbokiite compared to that of georgbokiite is reflected in the values of physical densities, which are equal to 4.88 and $4.69 \mathrm{~g}^{\mathrm{cm}} \mathrm{cm}^{-3}$ for the $\alpha$ - and $\beta$-polymorphs, respectively. According to Krivovichev et al. [47], parageorgbokiite is most likely a high-temperature modification of $\mathrm{Cu}_{5} \mathrm{O}_{2}\left(\mathrm{SeO}_{3}\right)_{2} \mathrm{Cl}_{2}$, however, the relative stabilities of the two minerals are unknown. It is of interest that, whereas georgbokiite can easily be synthesized by the chemical vapor transport reactions method $[55,71]$, no synthetic analogue is known for parageorgbokiite.

(a)

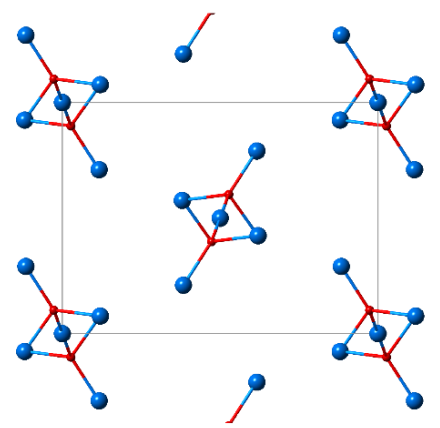

(c)

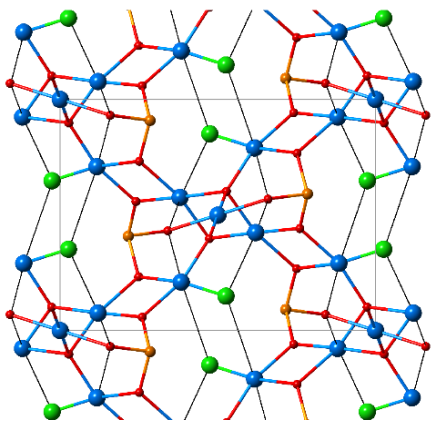

(b)

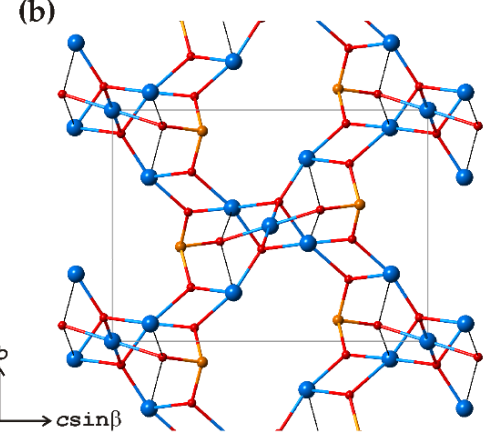

(d)

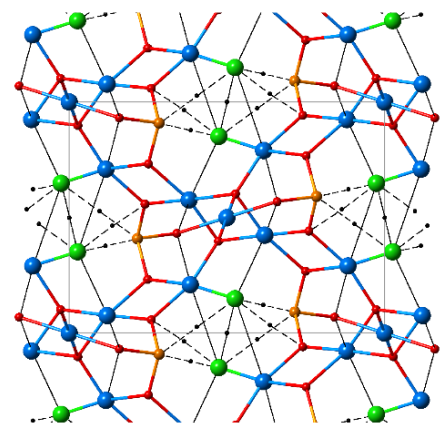

Figure 6. The scheme of successive (step-by-step) construction of the crystal structure of parageorgbokiite, $\beta-\mathrm{Cu}_{5} \mathrm{O}_{2}\left(\mathrm{SeO}_{3}\right)_{2} \mathrm{Cl}_{2}$ : (a) the arrangement of the $\left[\mathrm{O}_{2} \mathrm{Cu}_{5}\right]$ chains of edge- and corner-sharing $\left(\mathrm{OCu}_{4}\right)$ tetrahedra; $(\mathbf{b})$ the metal-oxide bonding network of the $\mathrm{Cu}-\mathrm{O}$ and Se-O bonds; (c) the structure projection showing the positions of the $\mathrm{Cl}$ atoms; (d) the location of bcps corresponding to weak closed-shell interactions. See text for details. Legend as in Figure 5.

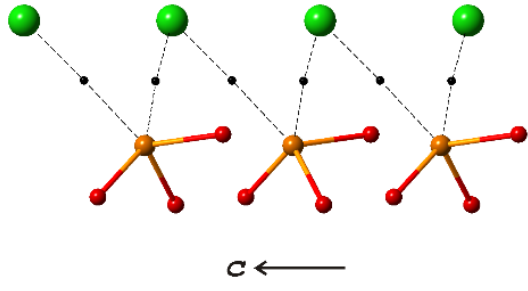

(a)

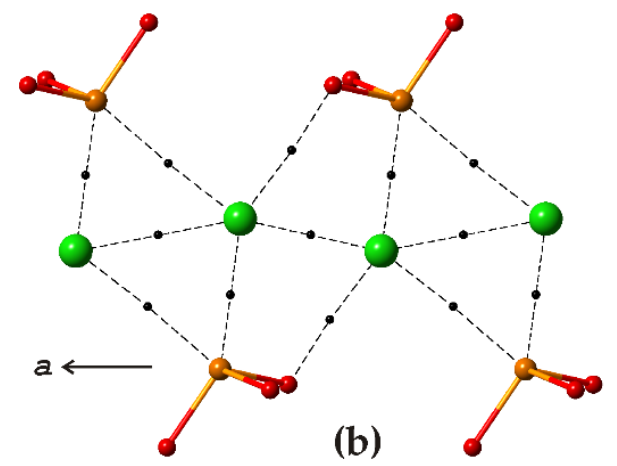

(b)

Figure 7. The arrangement of $\left(\mathrm{SeO}_{3}\right)$ groups and $\mathrm{Cl}$ atoms in the channels in the crystal structures of georgbokiite (a) and parageorgbokiite (b). Dashed lines indicate bond paths that correspond to weak closed-shell interactions. Legend as in Figure 5. 


\subsection{Burnsite, $\mathrm{KCdCu}_{7} \mathrm{O}_{2}\left(\mathrm{SeO}_{3}\right)_{2} \mathrm{Cl}_{9}$}

Burnsite, $\mathrm{KCdCu}_{7} \mathrm{O}_{2}\left(\mathrm{SeO}_{3}\right)_{2} \mathrm{Cl}_{9}$, was discovered in Tolbachik fumaroles in 2002 [18]. By analogy with $\mathrm{Cu}_{5} \mathrm{O}_{2}\left(\mathrm{SeO}_{3}\right)_{2} \mathrm{Cl}_{2}$ polymorphs, its crystal structure contains additional $\mathrm{O}$ atoms tetrahedrally coordinated by four $\mathrm{Cu}$ atoms [48]. Two $\left(\mathrm{OCu}_{4}\right)$ tetrahedra share a common $\mathrm{Cu}$ atom to form a $\left[\mathrm{O}_{2} \mathrm{Cu}_{7}\right]$ dimer (Figure $8 \mathrm{a}$ ) similar to those recently observed in the crystal structure of $\mathrm{Na}_{2} \mathrm{Cu}_{7} \mathrm{O}_{2}\left(\mathrm{SeO}_{3}\right)_{4} \mathrm{Cl}_{4}[72,73]$.

In the crystal structure of burnsite, the $\left[\mathrm{O}_{2} \mathrm{Cu}_{7}\right]$ dimers are surrounded by two $\left(\mathrm{SeO}_{3}\right)$ groups each of them attached to the $\left(\mathrm{OCu}_{4}\right)$ tetrahedra in a face-to-face fashion (Figure $\left.8 \mathrm{~b}\right)$. The resulting $\left\{\left[\mathrm{O}_{2} \mathrm{Cu}_{7}\right]\left(\mathrm{SeO}_{3}\right)_{2}\right\}$ groups are linked via $\mathrm{Cu}-\mathrm{O}$ bonds into an open three-dimensional framework (Figure 9a) with large cavities occupied by $\mathrm{Cd}^{2+}, \mathrm{K}^{+}$, and $\mathrm{Cl}^{-}$ions (Figure $9 \mathrm{~b}$ ).

Table 6 provides a list of bcps in the crystal structure of burnsite. It can be seen that most of the interatomic interactions can be described as belonging to the intermediate type with $\nabla^{2} \rho\left(\mathrm{r}_{\mathrm{c}}\right)>0$ and $H\left(\mathrm{r}_{\mathrm{c}}\right)<0$, except for the Se-Cl interactions that are of the closed-shell type $\left(\nabla^{2} \rho\left(\mathrm{r}_{\mathrm{c}}\right)>0\right.$ and $\left.H\left(\mathrm{r}_{\mathrm{c}}\right)>0\right)$. Figure $8 \mathrm{c}$ shows the atomic configuration inside the cavity occupied by two $\left(\mathrm{SeO}_{3}\right)$ groups and three $\mathrm{Cl}^{-}$ions.

Table 6. Bond critical points in the crystal structure of burnsite, $\mathrm{KCdCu}_{7} \mathrm{O}_{2}\left(\mathrm{SeO}_{3}\right)_{2} \mathrm{Cl}_{9}$, and their properties.

\begin{tabular}{ccccccccc}
\hline $\mathbf{A}_{\mathbf{1}}$ & $\mathbf{A}_{\mathbf{2}}$ & $\boldsymbol{d}[\mathbf{A}]$ & $\rho\left(\mathbf{r}_{\mathbf{c}}\right)$ & $\nabla^{2} \boldsymbol{\rho}\left(\mathbf{r}_{\mathbf{c}}\right)$ & $G\left(\mathbf{r}_{\mathbf{c}}\right)$ & $\boldsymbol{V}\left(\mathbf{r}_{\mathbf{c}}\right)$ & $\boldsymbol{H}\left(\mathbf{r}_{\mathbf{c}}\right)$ & $\mathbf{B D}$ \\
\hline $\mathrm{Cd}$ & $\mathrm{Cl} 1$ & 2.614 & 0.0426 & 0.1420 & 0.0395 & -0.0436 & -0.0041 & -0.096 \\
$\mathrm{Cu} 1$ & $\mathrm{O} 1$ & 1.899 & 0.1016 & 0.4263 & 0.1447 & -0.1828 & -0.0381 & -0.375 \\
$\mathrm{Cu} 1$ & $\mathrm{O} 2$ & 1.916 & 0.0906 & 0.4215 & 0.1362 & -0.1670 & -0.0308 & -0.340 \\
$\mathrm{Cu} 1$ & $\mathrm{O} 2$ & 2.127 & 0.0580 & 0.2304 & 0.0736 & -0.0896 & -0.0160 & -0.276 \\
$\mathrm{Cu} 1$ & $\mathrm{Cl} 2$ & 2.555 & 0.0369 & 0.1152 & 0.0331 & -0.0374 & -0.0043 & -0.117 \\
$\mathrm{Cu} 1$ & $\mathrm{Cl} 1$ & 2.612 & 0.0331 & 0.1101 & 0.0300 & -0.0324 & -0.0024 & -0.073 \\
$\mathrm{Cu} 2$ & $\mathrm{O} 1$ & 1.914 & 0.0980 & 0.4169 & 0.1409 & -0.1776 & -0.0367 & -0.374 \\
$\mathrm{Cu} 2$ & $\mathrm{Cl} 2$ & 2.451 & 0.0484 & 0.1460 & 0.0464 & -0.0562 & -0.0098 & -0.202 \\
$\mathrm{Se}$ & $\mathrm{O} 2$ & 1.687 & 0.1936 & 0.4591 & 0.2350 & -0.3553 & -0.1203 & -0.621 \\
$\mathrm{Se}$ & $\mathrm{Cl} 2$ & 3.532 & 0.0085 & 0.0270 & 0.0058 & -0.0048 & 0.0010 & 0.118 \\
\hline
\end{tabular}

Each $\left(\mathrm{SeO}_{3}\right)$ group forms participates in three $\mathrm{Se}-\mathrm{Cl}$ interactions, so that the full coordination of $\mathrm{Se}^{4+}$ ions can be viewed as trigonal prismatic, similar to that observed in the crystal structures of the $\mathrm{Zn}_{2}\left(\mathrm{SeO}_{3}\right) \mathrm{Cl}_{2}$ polymorphs (see above). Each $\mathrm{Cl}_{2}$ atom participates in two Cl-Se closed-shell interactions.
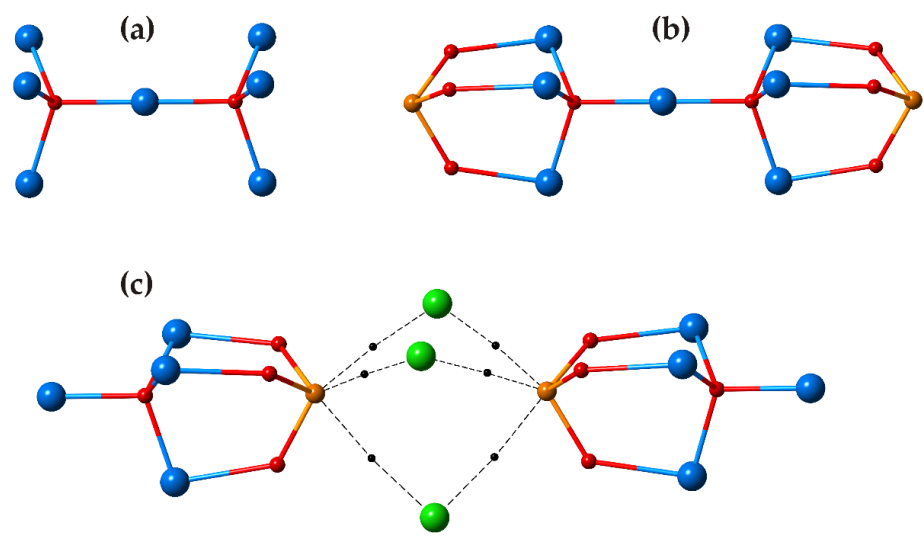

Figure 8. The $\left[\mathrm{O}_{2} \mathrm{Cu}_{7}\right]$ dimer of two corner-sharing $\left(\mathrm{OCu}_{4}\right)$ tetrahedra in the crystal structure of burnsite (a) and its coordination by two $\left(\mathrm{SeO}_{3}\right)$ groups $(\mathbf{b})$. The atomic configuration inside the metal-oxide framework cavity showing the orientation of $\mathrm{Se}-\mathrm{Cl}$ closed-shell interactions. (c) Legend as in Figure 5. 


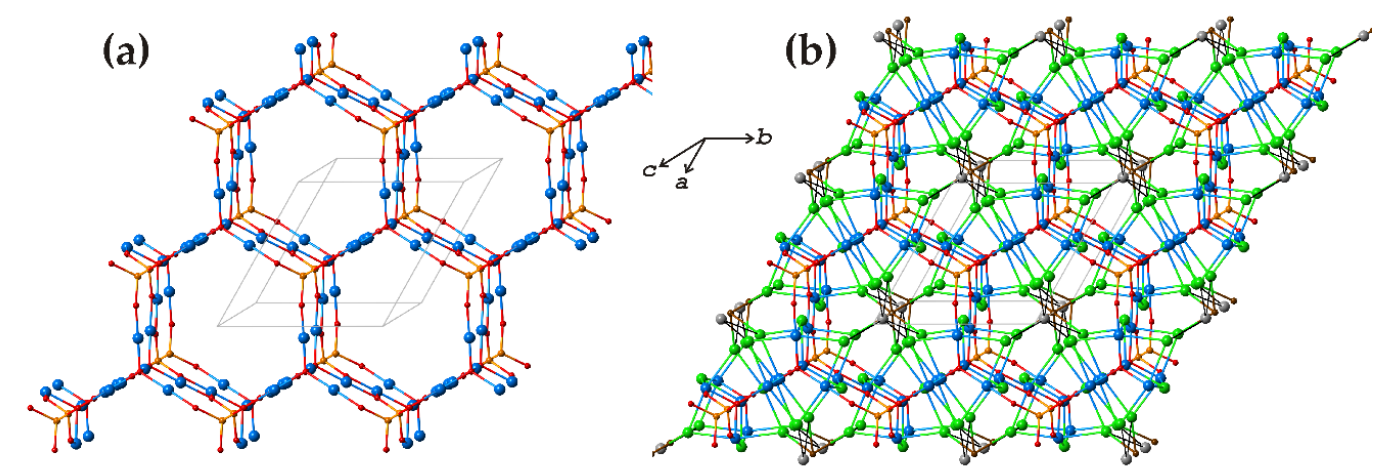

Figure 9. The open framework metal-oxide framework formed by $\left[\mathrm{O}_{2} \mathrm{Cu}_{7}\right]$ dimers and $\left(\mathrm{SeO}_{3}\right)$ groups in the crystal structure of burnsite (a) and the projection of the whole structure of burnsite featuring filling framework cavities by $\mathrm{Cd}^{2+}, \mathrm{K}^{+}$, and $\mathrm{Cl}^{-}$ions (b). Legend: $\mathrm{Cu}, \mathrm{Se}, \mathrm{O}, \mathrm{Cl}, \mathrm{K}$, and $\mathrm{Cd}$ atoms are shown as blue, orange, red, green, gray, and brown spheres, respectively.

\section{Conclusions}

The analysis of theoretical electron density distributions in selenite chlorides reveals the existence in their structures of two basic types of interactions: intermediate interactions with essential covalent contribution $\left[\nabla^{2} \rho\left(\mathbf{r}_{\mathbf{c}}\right)>0\right.$ and $\left.H\left(\mathbf{r}_{\mathbf{c}}\right)<0\right]$ and closed-shell interactions $\left[\nabla^{2} \rho\left(\mathbf{r}_{\mathbf{c}}\right)>0\right.$ and $\left.H\left(\mathbf{r}_{\mathbf{c}}\right)>0\right]$. In the $\mathrm{Zn}_{2}\left(\mathrm{SeO}_{3}\right) \mathrm{Cl}_{2}$ polymorphs and burnsite, all $M e-X$ interactions are of the first type, whereas, in georgbokiite and parageorgbokiite, the Jahn-Teller distortion of the $\mathrm{Cu}^{2+}$ coordination geometry results in the elongation of some of the $\mathrm{Cu}-X$ bonds and their transition to the closed-shell type. All anion-anion ( $\mathrm{Cl}-\mathrm{Cl}$ and $\mathrm{O}-\mathrm{O})$ interactions are of the closed-shell type as well, quite comparable with the previous observations of anion-anion bonding in inorganic salts [32].

The nature of the $\mathrm{Se}-\mathrm{Cl}$ interactions deserves special attention. The analysis of the bond-critical points of the Laplacian of the electron-density distribution indicates that, at least in selenite chlorides under consideration, it is different from that of the halogen or chalcogen bonds [74-76], i.e., it is not of the electron donor/electron acceptor type. The regions with concentrated and depleted regions of electron density around $\mathrm{Se}^{4+}$ and $\mathrm{Cl}^{-}$ions do not correlate with each other and are not aligned with the $\mathrm{Se}-\mathrm{Cl}$ bonding paths. However, the $\mathrm{Se}-\mathrm{Cl}$ interaction corresponds to the overlap of van der Waals radii: the typical $\mathrm{Se}-\mathrm{Cl}$ distance is selenite chlorides is in the range $3.30-3.55 \AA$, whereas the sum of the van der Waals radii $\left(R^{\mathrm{W}}\right)$ is equal to $R^{\mathrm{W}} \mathrm{Se}+R^{\mathrm{W}} \mathrm{Cl}=1.9+1.8=3.7 \AA$ [77]. The energy of the $\mathrm{Se}-\mathrm{Cl}$ closed-shell interactions, $E_{\mathrm{int}}$, can be estimated using the equation proposed by Espinosa et al. [78]:

$$
E_{\text {int }}=-313.754 V\left(\mathbf{r}_{\mathrm{c}}\right)
$$

where $V\left(\mathbf{r}_{\mathrm{c}}\right)$ is the potential electron energy density at bcp expressed in atomic units (a.u.). Taking into account that the $V\left(\mathbf{r}_{\mathrm{c}}\right)$ value in selenite chlorides analyzed above varies from -0.0083 to -0.0044 a.u., the energy of the $\mathrm{Se}-\mathrm{Cl}$ closed-shell interactions can be estimated as $1.4-2.6 \mathrm{kcal} \cdot \mathrm{mol}^{-1}$. This energy range is comparable to that observed for weak hydrogen bonds [79] or other weakly bonded configurations, e.g., weak $\mathrm{I}-\mathrm{O}$ bonds in $\alpha-\mathrm{HIO}_{3}$ [80], and anion-anion and cation-cation interactions [81,82]. Despite their weakness, these interactions provide additional stabilization of structural architectures. However, it should be noted that the Equation (2) was originally proposed for hydrogen-bonded interactions and its applicability to closed-shell interactions is not fully justified. It is also of interest that the presence of the $\mathrm{Se}-\mathrm{Cl}$ bonding interactions may at least in part explain the bond-valence deficiency frequently observed for $\mathrm{Cl}^{-}$anions in natural selenite chlorides [22,42,47,48]. Our conclusion about the closed-shell nature of the $\mathrm{Se}-\mathrm{Cl}$ interactions is also supported by the fact that the total net charges on Se atoms (calculated for sofiite and georgbokiite) are in the range of +6.05-6.07, which indicates that there is no correlation between these values and the number of $\mathrm{Se}-\mathrm{Cl}$ interactions per $\mathrm{Se}^{4+}$ cation. 
Thus, the existence of the large number of selenite chlorides and almost complete absence of selenate chlorides can be explained by the tendency of $\mathrm{Se}^{4+}$ cations possessing a lone electron pair to participate in attractive $\mathrm{Se}^{4+}-\mathrm{Cl}^{-}$interactions, which cannot be realized in $\mathrm{Se}^{6+}$ oxysalts. Though weak, these interactions seem to be of crucial importance for the stabilization of structural architectures with relatively hard intermediate metal-oxide interactions and relatively soft closed-shell interactions. The $\mathrm{Se}^{4+}-\mathrm{Cl}^{-}$configurations are localized inside framework channels or cavities, which can be therefore be viewed as regions of weak and soft interactions in the structure.

Author Contributions: Sergey V. Krivovichev conceived the idea of the manuscript; Sergey V. Krivovichev and Liudmila A. Gorelova performed the calculations and analyzed the data; Sergey V. Krivovichev wrote the paper.

Acknowledgments: We are grateful to three anonymous referees for very useful comments on the first version of this manuscript. This research was supported by the Russian Science Foundation (Grant 14-17-00071 to Sergey V. Krivovichev).

Conflicts of Interest: The authors declare no conflict of interest.

\section{References}

1. Hellenbrandt, M. The Inorganic Crystal Structure Database (ICSD)—Present and future. Crystallogr. Rev. 2004, 10, 17-22. [CrossRef]

2. Millet, P.; Bastide, B.; Pashchenko, V.; Gnatchenko, S.; Gapon, V.; Ksarid, Y.; Stepanov, A. Syntheses, crystal structures and magnetic properties of francisite compounds $\mathrm{Cu}_{3} \mathrm{Bi}\left(\mathrm{SeO}_{3}\right)_{2} \mathrm{O}_{2} \mathrm{X}(\mathrm{X}=\mathrm{Cl}, \mathrm{Br}$ and I). J. Mater. Chem. 2001, 11, 1152-1157. [CrossRef]

3. Shen, Y.-L.; Mao, J.-G.; Jiang, H.-L. Synthesis, crystal structure and magnetic property of a new nickel selenite chloride: $\mathrm{Ni}_{5}\left(\mathrm{SeO}_{3}\right)_{4} \mathrm{Cl}_{2}$. J. Solid State Chem. 2005, 178, 2942-2946. [CrossRef]

4. Becker, R.; Prester, M.; Berger, H.; Lin, P.H.; Johnsson, M.; Drobac, D.; Zivkovic, I. Crystal structure and magnetic properties of two new cobalt selenite halides: $\mathrm{Co}_{5}\left(\mathrm{SeO}_{3}\right)_{4} \mathrm{X}_{2}(\mathrm{X}=\mathrm{Cl}, \mathrm{Br})$. J. Solid State Chem. 2007, 180, 1051-1059. [CrossRef]

5. Zhang, D.; Berger, H.; Kremer, R.K.; Wulferding, D.; Lemmens, P.; Johnsson, M. Synthesis, crystal structure, and magnetic properties of the copper selenite chloride $\mathrm{Cu}_{5}\left(\mathrm{SeO}_{3}\right)_{4} \mathrm{Cl}_{2}$. Inorg. Chem. 2010, 49, 9683-9688. [CrossRef] [PubMed]

6. Berdonosov, P.S.; Janson, O.; Olenev, A.V.; Krivovichev, S.V.; Rosner, H.; Dolgikh, V.A.; Tsirlin, A.A. Crystal structures and variable magnetism of $\mathrm{PbCu}_{2}\left(\mathrm{XO}_{3}\right)_{2} \mathrm{Cl}_{2}$ with $\mathrm{X}=\mathrm{Se}$, Te. Dalton Trans. 2013, 42, 9547-9554. [CrossRef] [PubMed]

7. Berdonosov, P.S.; Kuznetsova, E.S.; Dolgikh, V.A.; Sobolev, A.V.; Presniakov, I.A.; Olenev, A.V.; Rahaman, B.; Saha-Dasgupta, T.; Zakharov, K.V.; Zvereva, E.A.; et al. Crystal structure, physical properties, and electronic and magnetic structure of the spin $S=5 / 2$ zigzag chain compound $\mathrm{Bi}_{2} \mathrm{Fe}\left(\mathrm{SeO}_{3}\right)_{2} \mathrm{OCl}_{3}$. Inorg. Chem. 2014, 53, 5830-5838. [CrossRef] [PubMed]

8. Zakharov, K.V.; Zvereva, E.A.; Berdonosov, P.S.; Kuznetsova, E.S.; Dolgikh, V.A.; Clark, L.; Black, C.; Lightfoot, P.; Kockelmann, W.; Pchelkina, Z.V.; et al. Thermodynamic properties, electron spin resonance, and underlying spin model in $\mathrm{Cu}_{3} \mathrm{Y}\left(\mathrm{SeO}_{3}\right)_{2} \mathrm{O}_{2} \mathrm{Cl}$. Phys. Rev. B 2014, 90, 214417. [CrossRef]

9. Markina, M.M.; Zakharov, K.V.; Zvereva, E.A.; Denisov, R.S.; Berdonosov, P.S.; Dolgikh, V.A.; Kuznetsova, E.S.; Olenev, A.V.; Vasiliev, A.N. Static and dynamic magnetic properties of two synthetic francisites $\mathrm{Cu}_{3} \mathrm{La}\left(\mathrm{SeO}_{3}\right)_{2} \mathrm{O}_{2} \mathrm{X}(\mathrm{X}=\mathrm{Br}$ and $\mathrm{Cl})$. Phys. Chem. Miner. 2017, 44, 277-285. [CrossRef]

10. Badrtdinov, D.I.; Kuznetsova, E.S.; Verchenko, V.Y.; Berdonosov, P.S.; Dolgikh, V.A.; Mazurenko, V.V.; Tsirlin, A.A. Magnetism of coupled spin tetrahedra in ilinskite-type $\mathrm{KCu}_{5} \mathrm{O}_{2}\left(\mathrm{SeO}_{3}\right)_{2} \mathrm{Cl}_{3}$. Sci. Rep. 2018, 8, 2379. [CrossRef] [PubMed]

11. Berdonosov, P.S.; Kuznetsova, E.S.; Dolgikh, V.A. Transition metal selenite halides: A fascinating family of magnetic compounds. Crystals 2018, 8, 159. [CrossRef]

12. Vergasova, L.P.; Filatov, S.K.; Semenova, T.F.; Filosofova, T.M. Sofiite $\mathrm{Zn}_{2}\left(\mathrm{SeO}_{3}\right) \mathrm{Cl}_{2}-\mathrm{A}$ new mineral from volcanic sublimates. Zap. Vses. Mineral. Obshch. 1989, 118, 65-69. (In Russian)

13. Pring, A.; Gatehouse, B.M.; Birch, W.D. Francisite, $\mathrm{Cu}_{3} \mathrm{Bi}_{(}\left(\mathrm{SeO}_{3}\right)_{2} \mathrm{O}_{2} \mathrm{Cl}$, new mineral from Iron Monarch, South Australia: Description and crystal structure. Am. Mineral. 1990, 75, 1421-1425. 
14. Vergasova, L.P.; Semenova, T.F.; Shuvalov, R.R.; Filatov, S.K.; Anan'yev, V.V. Ilinskite $\mathrm{NaCu}_{5} \mathrm{O}_{2}\left(\mathrm{SeO}_{3}\right)_{2} \mathrm{Cl}_{3}-\mathrm{A}$ new mineral of volcanic exhalations. Dokl. Akad. Nauk 1997, 353, 641-644. (In Russian)

15. Vergasova, L.; Krivovichev, S.; Semenova, T.; Filatov, S.; Ananiev, V. Chloromenite, $\mathrm{Cu}_{9} \mathrm{O}_{2}\left(\mathrm{SeO}_{3}\right)_{4} \mathrm{Cl}_{6}$, a new mineral from the Tolbachik volcano, Kamchatka, Russia. Eur. J. Mineral. 1999, 11, 119-123. [CrossRef]

16. Vergasova, L.P.; Semenova, T.F.; Filatov, S.K.; Krivovichev, S.V.; Shuvalov, R.R.; Ananiev, V.V. Georgbokiite $\mathrm{Cu}_{5} \mathrm{O}_{2}\left(\mathrm{SeO}_{3}\right)_{2} \mathrm{Cl}_{2}$ - A new mineral from volcanic sublimates. Dokl. Akad. Nauk 1999, 364, 527-531. (In Russian)

17. Campostrini, I.; Gramaccioli, C.M.; Demartin, F. Orlandiite, $\mathrm{Pb}_{3} \mathrm{Cl}_{4}\left(\mathrm{SeO}_{3}\right) \cdot \mathrm{H}_{2} \mathrm{O}$, a new mineral species, and an associated lead-copper selenite chloride from the Baccu Locci mine, Sardinia, Italy. Can. Mineral. 1999, 37, 1493-1498.

18. Krivovichev, S.V.; Vergasova, L.P.; Starova, G.L.; Filatov, S.K.; Britvin, S.N.; Roberts, A.C.; Steele, I.M. Burnsite, $\mathrm{KCdCu}_{7} \mathrm{O}_{2}\left(\mathrm{SeO}_{3}\right)_{2} \mathrm{Cl}_{9}$, a new mineral species from the Tolbachik Volcano, Kamchatka Peninsula, Russia. Can. Mineral. 2002, 40, 1171-1175. [CrossRef]

19. Vergasova, L.P.; Krivovichev, S.V.; Britvin, S.N.; Filatov, S.K.; Burns, P.C.; Ananyev, V.V. Allochalcoselite, $\mathrm{Cu}^{+} \mathrm{Cu}^{2+}{ }_{5} \mathrm{PbO}_{2}\left(\mathrm{SeO}_{3}\right)_{2} \mathrm{Cl}_{5}-\mathrm{A}$ new mineral from volcanic exhalations (Kamchatka, Russia). Zap. Ross. Mineral. Obshch. 2005, 134, 70-74. (In Russian)

20. Vergasova, L.P.; Krivovichev, S.V.; Filatov, S.K.; Britvin, S.N.; Burns, P.C.; Ananyev, V.V. Parageorgbokiite, $\beta-\mathrm{Cu}_{5} \mathrm{O}_{2}\left(\mathrm{SeO}_{3}\right)_{2} \mathrm{Cl}_{2}-\mathrm{A}$ new mineral from volcanic exhalations (Kamchatka peninsula, Russia). Zap. Ross. Mineral. Obshch. 2006, 135, 24-28. [CrossRef]

21. Gemmi, M.; Campostrini, I.; Demartin, F.; Gorelik, T.E.; Gramaccioli, C.M. Structure of the new mineral sarrabusite, $\mathrm{Pb}_{5} \mathrm{CuCl}_{4}\left(\mathrm{SeO}_{3}\right)_{4}$, solved by manual electron-diffraction tomography. Acta Crystallogr. 2012, B68, 15-23. [CrossRef] [PubMed]

22. Shuvalov, R.R.; Vegasova, L.P.; Semenova, T.F.; Filatov, S.K.; Krivovichev, S.V.; Siidra, O.I.; Rudashevsky, N.S. Prewittite, KPb1.5Cu6Zn(SeO3)2O2Cl10, a new mineral from Tolbachik fumaroles, Kamchatka peninsula, Russia: Description and crystal structure. Am. Mineral. 2013, 98, 463-469. [CrossRef]

23. Vergasova, L.P.; Semenova, T.F.; Krivovichev, S.V.; Filatov, S.K.; Zolotarev, A.A., Jr.; Ananiev, V.V. Nicksobolevite, $\mathrm{Cu}_{7}\left(\mathrm{SeO}_{3}\right)_{2} \mathrm{O}_{2} \mathrm{Cl}_{6}$, a new complex copper oxoselenite chloride from Tolbachik fumaroles, Kamchatka peninsula, Russia. Eur. J. Mineral. 2014, 26, 439-449. [CrossRef]

24. Johnsson, M.; Tornroos, K.W.; Lemmens, P.; Millet, P. Crystal structure and magnetic properties of a new two-dimensional $S=1$ quantum system $\mathrm{Ni}_{5}\left(\mathrm{TeO}_{3}\right)_{3} \mathrm{X}_{2}(\mathrm{X}=\mathrm{Cl}, \mathrm{Br})$. Chem. Mater. 2003, 15, 68-73. [CrossRef]

25. Bader, R.F.W. Atoms in Molecules; Oxford Science Publications: Oxford, UK, 1990; ISBN 9780198558651.

26. Gatti, C. Chemical bonding in crystals: New directions. Z. Kristallogr. 2005, 220, 399-457. [CrossRef]

27. Espinosa, E.; Alkorta, I.; Elguero, J.; Molins, E. From weak to strong interactions: A comprehensive analysis of the topological and energetic properties of the electron density distribution involving $\mathrm{X}-\mathrm{H} \cdots \mathrm{F}-\mathrm{Y}$ systems. J. Chem. Phys. 2002, 117, 5529-5542. [CrossRef]

28. Pendás, A.M.; Costales, A.; Luaña, V. Ions in crystals: The topology of the electron density in ionic materials. I. Fundamentals. Phys. Rev. B 1997, 55, 4275. [CrossRef]

29. Vegas, A.; Santamaria-Perez, D.; Marques, M.; Florez, M.; Garcia-Baonza, V.; Recio, J.M. Anions in metallic matrices model: Application to the aluminium crystal chemistry. Acta Crystallogr. 2006, B62, 220-227. [CrossRef] [PubMed]

30. Dunitz, J.D. Intermolecular atom-atom bonds in crystals? IUCr] 2015, 2, 157-158. [CrossRef] [PubMed]

31. Lecomte, C.; Espinosa, E.; Matta, C.F. On atom-atom 'short contact' bonding interactions in crystals. IUCrJ 2015, 2, 161-163. [CrossRef] [PubMed]

32. Nelyubina, Y.V.; Antipin, M.Y.; Lyssenko, K.A. Anion-anion interactions: Their nature, energy and role in crystal formation. Russ. Chem. Rev. 2010, 79, 167-187. [CrossRef]

33. Gibbs, G.V.; Downs, R.T.; Cox, D.F.; Ross, N.L.; Boisen, M.B., Jr.; Rosso, K.M. Shared and closed-shell O-O interactions in silicates. J. Phys. Chem. A 2008, 112, 3693-3699. [CrossRef] [PubMed]

34. Gibbs, G.V.; Wallace, A.F.; Cox, D.F.; Dove, P.M.; Downs, R.T.; Ross, N.L.; Rosso, K.M. Role of directed van der Waals bonded interactions in the determination of the structures of molecular arsenate solids. J. Phys. Chem. A 2009, 113, 736-749. [CrossRef] [PubMed]

35. Gibbs, G.V.; Wallace, A.F.; Zallen, R.; Downs, R.T.; Ross, N.L.; Cox, D.F.; Rosso, K.M. Bond paths and van der Waals interactions in orpiment, $\mathrm{As}_{2} \mathrm{~S}_{3}$. J. Phys. Chem. A 2010, 114, 6550-6557. [CrossRef] [PubMed] 
36. Gibbs, G.V.; Wallace, A.F.; Downs, R.T.; Ross, N.L.; Cox, D.F.; Rosso, K.M. Thioarsenides: A case for long-range Lewis acid-base-directed van der Waals interactions. Phys. Chem. Miner. 2011, 38, $267-291$. [CrossRef]

37. Krivovichev, S.V.; Burns, P.C. Crystal chemistry of lead oxide chlorides. I. Crystal structures of synthetic mendipite, $\mathrm{Pb}_{3} \mathrm{O}_{2} \mathrm{Cl}_{2}$, and synthetic damaraite, $\mathrm{Pb}_{3} \mathrm{O}_{2}(\mathrm{OH}) \mathrm{Cl}$. Eur. J. Mineral. 2001, 13, 801-809. [CrossRef]

38. Krivovichev, S.V.; Armbruster, T.; Depmeier, W. Crystal structures of $\mathrm{Pb}_{8} \mathrm{O}_{5}\left(\mathrm{AsO}_{4}\right)_{2}$ and $\mathrm{Pb}_{5} \mathrm{O}_{4}\left(\mathrm{CrO}_{4}\right)$, and review of PbO-related structural units in inorganic compounds. J. Solid State Chem. 2004, 177, 1321-1332. [CrossRef]

39. Krivovichev, S.V.; Siidra, O.I.; Nazarchuk, E.V.; Burns, P.C.; Depmeier, W. Particular topological complexity of lead oxide blocks in $\mathrm{Pb}_{31} \mathrm{O}_{22} \mathrm{X}_{18}(\mathrm{X}=\mathrm{Br}, \mathrm{Cl})$. Inorg. Chem. 2006, 45, 3846-3848. [CrossRef] [PubMed]

40. Krivovichev, S.V.; Armbruster, T.; Depmeier, W. One-dimensional lone electron pair micelles in the crystal structure of $\mathrm{Pb}_{5}\left(\mathrm{SiO}_{4}\right)\left(\mathrm{VO}_{4}\right)_{2}$. Mater. Res. Bull. 2004, 39, 1717-1722. [CrossRef]

41. Krivovichev, S.V.; Burns, P.C. Crystal chemistry of uranyl molybdates. VIII. Crystal structures of $\quad \mathrm{Na}_{3} \mathrm{Tl}_{3}\left[\left(\mathrm{UO}_{2}\right)\left(\mathrm{MoO}_{4}\right)_{4}\right], \quad \mathrm{Na}_{3} \mathrm{Tl}_{3}\left[\left(\mathrm{UO}_{2}\right)\left(\mathrm{MoO}_{4}\right)_{3}\right]_{4}\left(\mathrm{H}_{2} \mathrm{O}\right)_{5}, \quad \mathrm{Na}_{3} \mathrm{Tl}_{5}\left[\left(\mathrm{UO}_{2}\right)\left(\mathrm{MoO}_{4}\right)_{3}\right]_{2}\left(\mathrm{H}_{2} \mathrm{O}\right)_{3}$ and $\mathrm{Na}_{2}\left[\left(\mathrm{UO}_{2}\right)\left(\mathrm{MoO}_{4}\right)_{2}\right]\left(\mathrm{H}_{2} \mathrm{O}\right)_{4}$. Can. Mineral. 2003, 41, 707-719. [CrossRef]

42. Krivovichev, S.V.; Filatov, S.K.; Burns, P.C.; Vergasova, L.P. The crystal structure of allochalcoselite, $\mathrm{Cu}^{+} \mathrm{Cu}^{2+}{ }_{5} \mathrm{PbO}_{2}\left(\mathrm{SeO}_{3}\right)_{2} \mathrm{Cl}_{5}$, a mineral with well-defined $\mathrm{Cu}^{+}$and $\mathrm{Cu}^{2+}$ positions. Can. Miner. 2006, 44, 507-514. [CrossRef]

43. Krivovichev, S.V.; Filatov, S.K.; Vergasova, L.P. The crystal structure of ilinskite, $\mathrm{NaCu}_{5} \mathrm{O}_{2}\left(\mathrm{SeO}_{3}\right)_{2} \mathrm{Cl}_{3}$, and review of mixed-ligand $\mathrm{CuO}_{\mathrm{m}} \mathrm{Cl}_{\mathrm{n}}$ coordination geometries in minerals and inorganic compounds. Miner. Petrol. 2013, 107, 235-242. [CrossRef]

44. Semenova, T.F.; Rozhdestvenskaya, I.V.; Filatov, S.K.; Vergasova, L.P. Crystal structure and physical properties of sophiite, $\mathrm{Zn}_{2}\left(\mathrm{SeO}_{3}\right) \mathrm{Cl}_{2}$, a new mineral. Mineral. Mag. 1992, 56, 241-245. [CrossRef]

45. Johnsson, M.; Tornroos, K.W. Zinc selenium oxochloride, $\beta-\mathrm{Zn}_{2}\left(\mathrm{SeO}_{3}\right) \mathrm{Cl}_{2}$, a synthetic polymorph of the mineral sophiite. Acta Crystallogr. C 2007, 63, i34-i36. [CrossRef] [PubMed]

46. Krivovichev, S.V.; Shuvalov, R.R.; Semenova, T.F.; Filatov, S.K. Crystal chemistry of inorganic compounds based on chains of oxocentered tetrahedra. III. Crystal structure of georgbokiite, $\mathrm{Cu}_{5} \mathrm{O}_{2}\left(\mathrm{SeO}_{3}\right)_{2} \mathrm{Cl}_{2}$. Z. Kristallogr. 1999, 214, 135-138. [CrossRef]

47. Krivovichev, S.V.; Filatov, S.K.; Burns, P.C.; Vergasova, L.P. The crystal structure of parageorgbokiite, $\beta-\mathrm{Cu}_{5} \mathrm{O}_{2}\left(\mathrm{SeO}_{3}\right)_{2} \mathrm{Cl}_{2}$. Can. Mineral. 2007, 45, 929-934. [CrossRef]

48. Burns, P.C.; Krivovichev, S.V.; Filatov, S.K. New $\mathrm{Cu}^{2+}$ coordination polyhedra in the crystal structure of burnsite, $\mathrm{KCdCu}_{7} \mathrm{O}_{2}\left(\mathrm{SeO}_{3}\right)_{2} \mathrm{Cl}_{9}$. Can. Mineral. 2002, 40, 1587-1595. [CrossRef]

49. Dovesi, R.; Orlando, R.; Erba, A.; Zicovich-Wilson, C.M.; Civalleri, B.; Casassa, S.; Maschio, L.; Ferrabone, M.; De La Pierre, M.; D'Arco, P.; et al. CRYSTAL14: A program for $a b$ initio investigation of crystalline solids. Int. J. Quantum Chem. 2014, 114, 1287-1317. [CrossRef]

50. Peintinger, M.F.; Oliveira, D.V.; Bredow, T. Consistent Gaussian basis sets of triple-zeta valence with polarization quality for solid-state calculations. J. Comput. Chem. 2013, 34, 451-459. [CrossRef] [PubMed]

51. Dou, Y.; Egdell, R.G.; Law, D.S.L.; Harrison, N.M.; Searle, B.G. An experimental and theoretical investigation of the electronic structure of CdO. J. Phys. Condens. Matter 1998, 10, 8447-8458. [CrossRef]

52. Gatti, C.; Casassa, S. TOPOND14. User's Manual; CNR-ISTM of Milano: Milano, Italy, 2013.

53. Gatti, C.; Saunders, V.R.; Roetti, C. Crystal field effects on the topological properties of the electron density in molecular crystals. The case of urea. J. Chem. Phys. 1994, 101, 10686-10696. [CrossRef]

54. Kovrugin, V.M.; Siidra, O.I.; Colmont, M.; Mentré, O.; Krivovichev, S.V. Emulating exhalative chemistry: Synthesis and structural characterization of ilinskite, $\mathrm{Na}\left[\mathrm{Cu}_{5} \mathrm{O}_{2}\right]\left(\mathrm{SeO}_{3}\right)_{2} \mathrm{Cl}_{3}$, and its $\mathrm{K}$-analogue. Miner. Petrol. 2015, 109, 421-430. [CrossRef]

55. Galy, J.; Bonnet, J.J.; Andersson, S. The crystal structure of a new oxide chloride of copper(II) and selenium(IV) $\mathrm{Cu}_{5} \mathrm{Se}_{2} \mathrm{O}_{8} \mathrm{Cl}_{2}$. Acta Chem. Scand. 1979, A33, 383-389. [CrossRef]

56. Bergerhoff, G.; Paeslack, J. Sauerstoff als Koordinationszentrum in Kristallstrukturen. Z. Kristallogr. 1968, 126, 112-123. [CrossRef]

57. Krivovichev, S.V.; Mentré, O.; Siidra, O.I.; Colmont, M.; Filatov, S.K. Anion-centered tetrahedra in inorganic compounds. Chem. Rev. 2013, 113, 6459-6535. [CrossRef] [PubMed]

58. Krivovichev, S.V. Structure description, interpretation and classification in mineralogical crystallography. Crystallogr. Rev. 2017, 23, 2-71. [CrossRef] 
59. Haas, H.; Jansen, M. Synthese und Charakterisierung von $\mathrm{Na}_{5} \mathrm{AsO}_{5}$. Z. Anorg. Allg. Chem. 2001, 627, 1013-1016. [CrossRef]

60. Krivovichev, S.V. Minerals with antiperovskite structure: A review. Z. Kristallogr. 2008, 223, 109-113. [CrossRef]

61. Reckeweg, O.; Blaschkowski, B.; Schleid, T. $\mathrm{Li}_{5} \mathrm{OCl}_{3}$ and $\mathrm{Li}_{3} \mathrm{OCl}$ : Two remarkably different lithium oxide chlorides. Z. Anorg. Allg. Chem. 2012, 638, 2081-2086. [CrossRef]

62. Nuss, J.; Muehle, C.; Hayama, K.; Abdolazimi, V.; Takagi, H. Tilting structures in inverse perovskites, $\mathrm{M}_{3} \mathrm{TtO}$ $(\mathrm{M}=\mathrm{Ca}, \mathrm{Sr}, \mathrm{Ba}, \mathrm{Eu} ; \mathrm{Tt}=\mathrm{Si}, \mathrm{Ge}, \mathrm{Sn}, \mathrm{Pb})$. Acta Crystallogr. 2015, B71, 300-312. [CrossRef]

63. Galuskin, E.V.; Gfeller, F.; Armbruster, T.; Galuskina, I.O.; Vapnik, Y.; Murashko, M.; Włodyka, R.; Dzierżanowski, P. New minerals with a modular structure derived from hatrurite from the pyrometamorphic Hatrurim Complex. Part I. Nabimusaite, $\mathrm{KCa}_{12}\left(\mathrm{SiO}_{4}\right)_{4}\left(\mathrm{SO}_{4}\right)_{2} \mathrm{O}_{2} \mathrm{~F}$, from larnite rocks of Jabel Harmun, Palestinian Autonomy, Israel. Mineral. Mag. 2015, 79, 1061-1072. [CrossRef]

64. Galuskin, E.V.; Gfeller, F.; Galuskina, I.O.; Pakhomova, A.; Armbruster, T.; Vapnik, Y.; Włodyka, R.; Dzierżanowski, P.; Murashko, M. New minerals with a modular structure derived from hatrurite from the pyrometamorphic Hatrurim Complex. Part II. Zadovite, $\mathrm{BaCa}_{6}\left[\left(\mathrm{SiO}_{4}\right)\left(\mathrm{PO}_{4}\right)\right]\left(\mathrm{PO}_{4}\right)_{2} \mathrm{~F}$ and aradite, $\mathrm{BaCa}_{6}\left[\left(\mathrm{SiO}_{4}\right)\left(\mathrm{VO}_{4}\right)\right]\left(\mathrm{VO}_{4}\right)_{2} \mathrm{~F}$, from paralavas of the Hatrurim Basin, Negev Desert, Israel. Mineral. Mag. 2015, 79, 1073-1087. [CrossRef]

65. Oudah, M.; Ikeda, A.; Hausmann, J.N.; Yonezawa, S.; Fukumoto, T.; Kobayashi, S.; Sato, M.; Maeno, Y. Superconductivity in the antiperovskite Dirac-metal oxide $\mathrm{Sr}_{3-\mathrm{x}} \mathrm{SnO}$. Nat. Commun. 2016, 12, 13617. [CrossRef] [PubMed]

66. Lai, K.T.; Antonyshyn, I.; Prots, Y.; Valldor, M. Anti-perovskite Li-battery cathode materials. J. Am. Chem. Soc. 2017, 139, 9645-9649. [CrossRef] [PubMed]

67. Krivovichev, S.V.; Starova, G.L.; Filatov, S.K. "Face-to-face” relationships between oxocentered tetrahedra and cation-centered tetrahedral oxyanions in crystal structures of minerals and inorganic compounds. Mineral. Mag. 1999, 63, 263-266. [CrossRef]

68. Krivovichev, S.V.; Filatov, S.K. Structural principles for minerals and inorganic compounds containing anion-centered tetrahedra. Am. Mineral. 1999, 84, 1099-1106. [CrossRef]

69. Jahn, H.A.; Teller, E. Stability of polyatomic molecules in degenerate electronic states. I. Orbital degeneracy. Proc. R. Soc. A 1937, A161, 220-235. [CrossRef]

70. Brown, I.D. The Chemical Bond in Inorganic Chemistry. The Bond Valence Model, 2nd ed.; Oxford University Press: Oxford, UK, 2016; ISBN 9780198742951.

71. Semenova, T.F.; Pankratova, O.Y.; Habanova, A.A.; Shuvalov, R.R. Synthesis of exhalation copper selenites analogues by chemical gas transport reactions method. Vestnik Sankt-Peterb. Univ. Ser. 4 Fiz. Khim. 2005, 2, 75-81. (In Russian)

72. Kovrugin, V.M.; Colmont, M.; Mentré, O.; Siidra, O.I.; Krivovichev, S.V. Dimers of oxocentred [OCu $]_{4}^{6+}$ tetrahedra in two novel copper selenite chlorides, $\mathrm{K}\left[\mathrm{Cu}_{3} \mathrm{O}\right]\left(\mathrm{SeO}_{3}\right)_{2} \mathrm{Cl}$ and $\mathrm{Na}_{2}\left[\mathrm{Cu}_{7} \mathrm{O}_{2}\right]\left(\mathrm{SeO}_{3}\right)_{4} \mathrm{Cl}_{4}$, and related minerals and inorganic compounds. Mineral Mag. 2016, 80, 227-238. [CrossRef]

73. Tang, Y.; Guo, W.; Zhang, S.; Xiang, H.; Cui, M.; He, Z. $\mathrm{Na}_{2} \mathrm{Cu}_{7}\left(\mathrm{SeO}_{3}\right)_{4} \mathrm{O}_{2} \mathrm{Cl}_{4}$ : A selenite chloride compound with $\mathrm{Cu}_{7}$ units showing spin-frustration and a magnetization plateau. Dalton Trans. 2016, 45, 8324-8326. [CrossRef] [PubMed]

74. Cavallo, G.; Metrangolo, P.; Milani, R.; Pilati, T.; Priimagi, A.; Resnati, G.; Terraneo, G. The halogen bond. Chem. Rev. 2016, 116, 2478-2601. [CrossRef] [PubMed]

75. Benz, S.; Macchione, M.; Verolet, Q.; Mareda, J.; Sakai, N.; Matile, S. Anion transport with chalcogen bonds. J. Am. Chem. Soc. 2016, 138, 9093-9096. [CrossRef] [PubMed]

76. Sánchez-Sanz, G.; Trujillo, C. Improvement of anion transport systems by modulation of chalcogen interactions: The influence of solvent. J. Phys. Chem. A 2018, 122, 1369-1377. [CrossRef] [PubMed]

77. Batsanov, S.S. Van der Waals radii of elements. Inorg. Mater. 2001, 37, 871-885. [CrossRef]

78. Espinosa, E.; Alkorta, I.; Rozas, I.; Elguero, J.; Molins, E. About the evaluation of the local kinetic, potential and total energy densities in closed-shell interactions. Chem. Phys. Lett. 2001, 336, 457-461. [CrossRef]

79. Desiraju, G.; Steiner, T. The Weak Hydrogen Bond in Structural Chemistry and Biology; Oxford University Press: Oxford, UK, 2001; ISBN 9780198509707.

80. Nelyubina, Y.V.; Antipin, M.Y.; Lyssenko, K.A. Extremely short halogen bond: The nature and energy of iodine-oxygen interactions in crystalline iodic acid. Mendeleev Commun. 2011, 21, 250-252. [CrossRef] 
81. Mata, I.; Alkorta, I.; Molins, E.; Espinosa, E. Electrostatics at the origin of the stability of phosphate-phosphate complexes locked by hydrogen bonds. ChemPhysChem 2012, 13, 1421-1424. [CrossRef] [PubMed]

82. Weinhold, F.; Klein, R.A. Anti-electrostatic hydrogen bonds. Angew. Chem. Int. Ed. 2014, 53, 11214-11217. [CrossRef] [PubMed] 